\title{
Airborne observations of aerosol microphysical properties and particle ageing processes in the troposphere above Europe
}

\author{
T. Hamburger ${ }^{1, *}$, G. McMeeking ${ }^{2, * *}$, A. Minikin ${ }^{1}$, A. Petzold ${ }^{1, * * *}$, H. Coe $^{2}$, and R. Krejci ${ }^{3}$ \\ ${ }^{1}$ Deutsches Zentrum für Luft- und Raumfahrt (DLR), Institut für Physik der Atmosphäre, Oberpfaffenhofen, \\ 82234 Wessling, Germany \\ ${ }^{2}$ School of Earth, Atmospheric and Environmental Sciences, University of Manchester, Manchester M13 9PL, UK \\ ${ }^{3}$ Department of Applied Environmental Science (ITM), Stockholm University, 10691 Stockholm, Sweden \\ * now at: Department of Applied Environmental Science (ITM), Stockholm University, 10691 Stockholm, Sweden \\ ** now at: Department of Atmospheric Science, Colorado State University, Fort Collins, CO 80523, USA \\ *** now at: Institut für Energie- und Klimaforschung IEK-8: Troposphäre, Forschungszentrum Jülich GmbH, \\ 52425 Jülich, Germany
}

Correspondence to: T. Hamburger (thomas.hamburger@itm.su.se)

Received: 2 August 2012 - Published in Atmos. Chem. Phys. Discuss.: 15 August 2012

Revised: 20 November 2012 - Accepted: 27 November 2012 - Published: 4 December 2012

\begin{abstract}
In-situ measurements of aerosol microphysical properties were performed in May 2008 during the EUCAARI-LONGREX campaign. Two aircraft, the FAAM BAe-146 and DLR Falcon 20, operated from Oberpfaffenhofen, Germany. A comprehensive data set was obtained comprising the wider region of Europe north of the Alps throughout the whole tropospheric column. Prevailing stable synoptic conditions enabled measurements of accumulating emissions inside the continental boundary layer reaching a maximum total number concentration of 19000 particles $\mathrm{cm}^{-3} \mathrm{stp}$. Ultra-fine particles as indicators for nucleation events were observed within the boundary layer during high pressure conditions and after updraft of emissions induced by frontal passages above $8 \mathrm{~km}$ altitude in the upper free troposphere. Aerosol ageing processes during air mass transport are analysed using trajectory analysis. The ratio of particles containing a non-volatile core $\left(250^{\circ} \mathrm{C}\right)$ to the total aerosol number concentration was observed to increase within the first 12 to $48 \mathrm{~h}$ from the particle source from 50 to $85 \%$ due to coagulation. Aged aerosol also features an increased fraction of accumulation mode particles of approximately $40 \%$ of the total number concentration. The presented analysis provides an extensive data set of tropospheric aerosol microphysical properties on a continental scale which can be used for atmospheric aerosol models and comparisons of satellite retrievals.
\end{abstract}

\section{Introduction}

Aerosol particles play a major role within the earth climate system by changing the atmospheric radiation budget through direct (Haywood and Boucher, 2000) and indirect effects (Lohmann and Feichter, 2005). The knowledge of the spatial and temporal distribution of aerosol particles and their properties is therefore crucial to describe atmospheric processes and their climatic effects. This paper highlights the results of in-situ measurements of aerosol-microphysical properties above Central Europe. The data were retrieved by airborne in-situ measurements performed aboard the DLR-Falcon 20 and FAAM BAe-146 aircraft during the EUCAARI-LONGREX (EUCAARI-LONG Range EXperiment) campaign in May 2008. Information about the EUCAARI project can be found in Kulmala et al. (2009, 2011). The collected data covers the whole tropospheric column from the continental boundary layer up to the tropopause level above selected regions and is analysed with respect to the source regions and transport pathways.

The atmospheric radiation budget is affected directly by extinction of light caused by aerosol particles. This process depends on several factors like the size, shape or the chemical composition of the particles (Bohren and Huffman, 1983; O'Connor et al., 2008; Dall'Osto et al., 2010; Esselborn et al., 2008; Weinzierl et al., 2011). These properties 
are strongly related to the particle source and the subsequent processing of the particle during its lifetime. The knowledge of the source region, the transport pathway and the meteorological conditions along the pathway are therefore crucial to analyse the aerosol properties at a certain time and location.

In addition to the direct aerosol effect, the particle properties have an important impact on the hygroscopicity of the aerosol and thus on the ability to form cloud condensation nuclei (CCN) (e.g. Stock et al., 2011). Different aerosol properties influence the availability of $\mathrm{CCN}$ and thus the formation and the lifecycle of clouds. Ageing of aerosol particles during air mass transport leads to a change in size, number, and chemical composition by condensation, coagulation and photochemical processes. Hence, the hygroscopic properties of the initial aerosol and the number of available CCN are changed (Roldin et al., 2011).

Considering the direct and indirect effects of aerosol particles on the earth climate a fundamental knowledge of the particle properties and their temporal and spatial variability in the atmosphere is required. In-situ observations showed that regional variations of aerosol microphysical properties lead to variations in the vertical column aerosol optical depth due to both, direct and indirect aerosol effects (Clarke and Kapustin, 2010). Different aerosol types feature different radiative forcing above various surface types. While primarily light scattering aerosols have a larger impact above surfaces with low albedo such as urban areas, light absorbing aerosols effect the radiative forcing above surfaces with high albedo, e.g. snow-covered mountain regions (Iorga et al., 2007). The aerosol direct radiative forcing during cloud free conditions above the continent can lead to a radiative cooling of the surface temperature and radiative heating within the planetary boundary layer resulting in a stabilisation of the lower troposphere. A positive feedback arises as the stable lower troposphere increases the possibility of further accumulation of aerosol particles (Péré et al., 2011).

Further feedbacks induced by aerosol radiative forcing may also have larger regional effects which show sensitivity to the type and location of the forcing. E.g. the change in short-lived-species like aerosols at northern mid-latitudes contributed to rapid warming of the Arctic climate (Shindell and Faluvegi, 2009). Further studies showed that aerosols, also comprising anthropogenic emissions of aerosols, can drive North Atlantic climate variability (Booth et al., 2012).

Emission data bases and aerosol models have been continuously improved in recent years to provide information on properties and processes of atmospheric aerosols. However, the knowledge of the spatial and temporal distribution of atmospheric aerosol particles still underlies major uncertainties leading to crucial uncertainties in estimating the aerosol climate effect (Forster et al., 2007). Measurements help to improve models and data-bases and thus, to decrease the current uncertainties (Laj et al., 2009). While there exists a welldeveloped network of ground based aerosol measurements in Europe (EUSAAR) (Asmi et al., 2011), airborne measure- ments of particle properties in the troposphere covering a wider area on a continental scale are rare. Airborne observation campaigns mostly cover areas on a regional scale (Ansmann et al., 2002; Minikin et al., 2003) or focus on certain altitude levels (Crumeyrolle et al., 2010; Voigt et al., 2010). Long-term airborne observations mostly of the upper troposphere/lower stratosphere have been carried out within the CARIBIC project on a monthly base using civil aircraft on transcontinental flights (Brenninkmeijer et al., 1999, 2007).

This paper outlines the major results of airborne in-situ measurements of aerosol microphysical properties on a continental scale throughout the tropospheric column above $\mathrm{Eu}-$ rope. The measurement flights were conducted from Oberpfaffenhofen, Germany in May 2008. Stable synoptic conditions allowed for measurements at comparable conditions during three weeks. The data provides vertical and regional information of microphysical particle properties. It provides evidence that ageing processes which affect the aerosol microphysical properties can be observed on a continental scale using aircraft measurements - although the measurements were conducted above the densely populated region of Europe which exhibits a vast diversity of different aerosol sources.

Chemical analysis of airborne measurements inside the boundary layer over Europe (Morgan et al., 2010a) and an analysis of black carbon measurements (McMeeking et al., 2010) are provided in accompanying papers. A detailed overview of the synoptic and pollution situation during the EUCAARI-LONGREX campaign can be found in Hamburger et al. (2011). In addition, Hamburger et al. (2011) compared the airborne observations to the EUSAAR ground sites at Hyytiälä, Vavihill, Mace Head, Hohenpeißenberg, Melpitz, and Cabauw.

The present paper covers the analysis of size distributions and aerosol mode resolved number concentrations of ultra-fine condensation nuclei, condensation nuclei, and accumulation mode particles in different vertical levels above the north-east of Germany and the Baltic Sea, the Benelux States (Belgium, Netherlands, and Luxembourg), Ireland, and South Germany. Next to the analysis of total number and number of accumulated particles, volatility analysis of number and volume is performed in combination with a detailed trajectory analysis to estimate the timescale of aerosol ageing processes.

\section{Methods}

\subsection{The EUCAARI-LONGREX aircraft field campaign}

The LONGREX aircraft campaign was part of the EUCAARI project (Kulmala et al., 2009). Aircraft campaigns provide the link between regional ground-based measurements and large scale information of atmospheric properties retrieved by satellite measurements. The LONGREX 
Table 1. Flight summary of DLR Falcon 20 and FAAM BAe-146 during the EUCAARI-LONGREX campaign containing take off time (T/O) and landing time (L) of the flights at local time (LT) and operational area.

\begin{tabular}{|c|c|c|c|c|c|c|c|}
\hline \multirow[b]{2}{*}{ Date } & \multicolumn{3}{|c|}{ DLR Falcon 20} & \multicolumn{3}{|c|}{ FAAM BAe-146 } & \multirow[b]{2}{*}{ Operational area } \\
\hline & Flight ID & $\mathrm{T} / \mathrm{O}$ & $\mathrm{L}$ & Flight ID & $\mathrm{T} / \mathrm{O}$ & $\mathrm{L}$ & \\
\hline \multirow[t]{2}{*}{6 May 2008} & $080506 a$ & $09: 36$ & $12: 25$ & b362 & 09:09 & $13: 51$ & Germany/Belgium and North Sea \\
\hline & 080506b & $15: 26$ & $18: 00$ & b363 & $15: 13$ & $18: 25$ & Germany/Belgium and North Sea \\
\hline 7 May 2008 & & & & b364 & $13: 27$ & $15: 51$ & South Germany \\
\hline \multirow[t]{2}{*}{8 May 2008} & $080508 \mathrm{a}$ & 08:08 & $11: 47$ & b365 & $08: 24$ & $12: 30$ & Germany/Poland and Baltic coast \\
\hline & $080508 b$ & $13: 45$ & $17: 31$ & b366 & $13: 54$ & $17: 09$ & Germany/Benelux \\
\hline 9 May 2008 & $080509 a$ & $11: 39$ & $15: 03$ & b367 & $12: 22$ & $16: 50$ & South Germany (aircraft intercomparison) \\
\hline \multirow{2}{*}{10 May 2008} & & & & b368 & 08:04 & 13:00 & Sweden/Finland/Baltic Sea \\
\hline & & & & b369 & $14: 30$ & $18: 12$ & Baltic Sea/Germany \\
\hline \multirow[t]{2}{*}{12 May 2008} & & & & b370 & $06: 15$ & $12: 36$ & Germany/Netherlands/North Sea \\
\hline & & & & b371 & $13: 51$ & 18:04 & Germany/Baltic Sea \\
\hline \multirow[t]{2}{*}{13 May 2008} & $080513 \mathrm{a}$ & $10: 41$ & $13: 55$ & b372 & $08: 56$ & $13: 28$ & Germany/Baltic Sea/English Coast \\
\hline & $080513 b$ & $14: 56$ & $17: 43$ & b373 & $14: 46$ & $18: 27$ & English Coast circuit/Western Ireland \\
\hline \multirow[t]{2}{*}{14 May 2008} & $080514 \mathrm{a}$ & $09: 16$ & $12: 58$ & b374 & 09:41 & $14: 39$ & Irish Sea/Atlantic Ocean south-west of Ireland \\
\hline & $080514 b$ & $14: 21$ & $16: 38$ & b375 & $15: 54$ & $18: 18$ & Transit from Ireland to Germany \\
\hline 20 May 2008 & $080520 \mathrm{a}$ & $10: 25$ & $14: 02$ & & & & Eastern Germany/Poland/Baltic Sea \\
\hline \multirow{2}{*}{21 May 2008} & $080521 \mathrm{a}$ & 07:59 & $11: 11$ & b379 & 08:03 & $13: 27$ & Germany/Benelux \\
\hline & $080521 b$ & $12: 31$ & $15: 10$ & & & & Germany/Benelux \\
\hline \multirow[t]{2}{*}{22 May 2008} & $080522 \mathrm{a}$ & $08: 55$ & $11: 55$ & b380 & $08: 57$ & $13: 20$ & Germany/Benelux/English Channel/England \\
\hline & $080522 b$ & $12: 44$ & $13: 44$ & & & & Germany/Benelux/English Channel/England \\
\hline 24 May 2008 & $080524 \mathrm{a}$ & $06: 26$ & $10: 22$ & & & & South Germany/Austria \\
\hline
\end{tabular}

campaign focussed on the horizontal and vertical distribution of aerosol and trace gases on a continental scale throughout the tropospheric column. The aim was to examine the evolution of aerosol properties along west-east and northsouth transects including semi-lagrangian flights. The semilagrangian flights were designed to observe the transformation processes during air mass transport within the boundary layer or long-range transport in the free troposphere. However, the completion of semi-lagrangian flights was strongly limited by the meteorological conditions and air traffic restrictions within the highly frequented European air space. The aircraft were limited to real air routes due to restrictions of the national air traffic controls (ATC). Hence, trajectory calculations were used for source apportionment to account for the measured transformation processes.

The measurement flights were performed from Oberpfaffenhofen in May 2008 using two aircraft, the British aircraft FAAM BAe-146 (Facility for Airborne Atmospheric Measurements) operated by Directflight and the German DLR Falcon 20 operated by the Deutsches Zentrum für Luft- und Raumfahrt (DLR). A total of 15 DLR Falcon 20 flights and 16 FAAM BAe-146 flights were performed within the EUCAARI-LONGREX campaign (Table 1). Thereby 17 flights were performed during the morning hours and at noon time and 14 flights during the afternoon (McMeeking et al., 2010; Hamburger, 2011). Thus, the retrieved data span the whole daytime. The flights covered a region above $\mathrm{Eu}-$ rope from $15^{\circ} \mathrm{W}-25^{\circ} \mathrm{E}$ and $45^{\circ} \mathrm{N}-60^{\circ} \mathrm{N}$ up to $12 \mathrm{~km}$ altitude (Fig. 1). The FAAM BAe-146 focussed on chemical, opti- cal and microphysical aerosol properties and trace gas measurements inside the boundary layer (Morgan et al., 2010a,b; McMeeking et al., 2010; Highwood et al., 2012) whereas the DLR Falcon 20 measured aerosol microphysical and optical properties and trace gases basically in the free troposphere (Mirme et al., 2010; Hamburger et al., 2011). In addition a light detection and ranging (LIDAR) system was installed aboard the DLR Falcon 20 (Esselborn et al., 2008) to detect layers of enhanced aerosol loadings in the atmosphere beneath the aircraft. Eventually, these layers could be successfully observed by in-situ measurements of both aircraft (see e.g. Kulmala et al., 2011, Fig. 9 therein).

The DLR Falcon 20 flew stacked horizontal legs with an approximate duration of $5 \mathrm{~min}$ each at different altitudes to obtain in-situ measurements throughout the tropospheric column above certain regions. These so called vertical profiles have a horizontal extension of approximately $50-100 \mathrm{~km}$ and reach a vertical extension of $10-12 \mathrm{~km}$. Vertical profiles and overflights of ground stations performed by the DLR Falcon 20 were conducted in the larger regions of the EUSAAR sites Melpitz, Hohenpeißenberg, Mace Head, Vavihill, and Cabauw (Hamburger et al., 2011). The regions for the vertical profiles were limited by ATC like the air routes. Thus, vertical profiles frequently had to be performed during takeoff and landing and in Temporary Reserved Areas (TRA). The flight tracks of the two aircraft and the regions covered by the vertical profiles performed by the DLR Falcon 20 are shown in Fig. 1. 


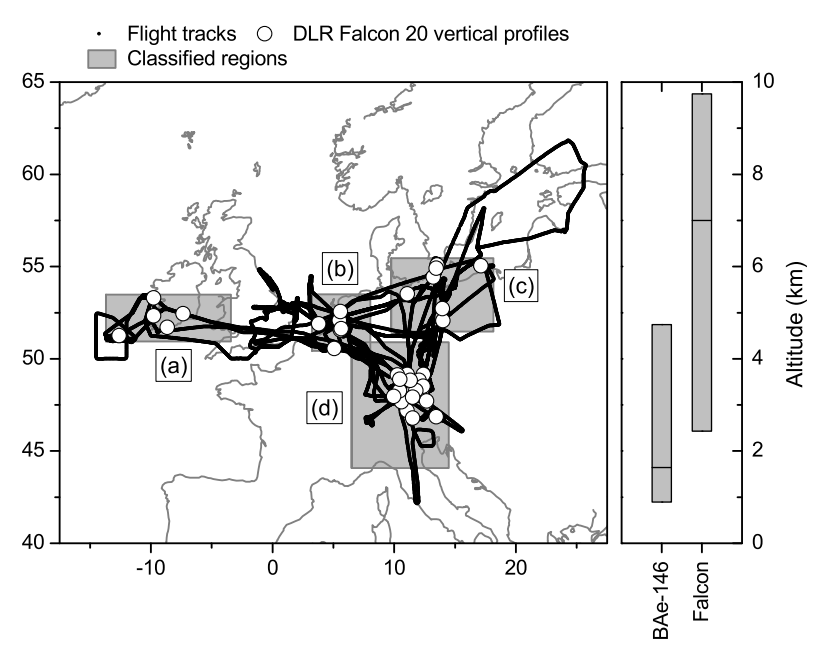

Fig. 1. Flight tracks of DLR Falcon 20 and FAAM BAe-146 during the EUCAARI-LONGREX campaign (black lines). The black circles denote the position of vertical in-situ profiles measured aboard the DLR Falcon 20. The grey shades depict the regions used for the classification of vertical profiles (see Section 3.4): Ireland (a), Benelux States (b), North-east Germany and Baltic Sea (c), and South Germany (d). The box plot in the right panel shows the vertical extension of the measurement flights (median and 1 st and 3 rd quartiles).

Two distinct synoptic periods occurred during the EUCAARI-LONGREX campaign in May 2008 (Hamburger et al., 2011). The first period (a) lasted for the first half of May and was defined by a persistent high pressure system leading to stable and dry meteorological conditions and an anticyclonic flow over Central and Northern Europe. The prevailing air mass transport direction followed a pathway from the Baltic Sea via North Germany and The Netherlands to the south of England and Ireland. Frontal passages occurred during the second period (b) in the second half of May. The cyclones mainly affected Southern and Central Europe. The anticyclonic flow evolved again in Northern Europe after the occurrence of frontal passages in mid of May.

\subsection{Measurements}

Particle number concentrations were measured aboard the DLR Falcon 20 using a custom build condensation particle size analyser (CPSA) (Fiebig et al., 2005; Feldpausch et al., 2006) and a condensation particle counter (CPC, TSI model 3760). The CPSA consists of a battery of four condensation particle counters which can be set to different lower cutoff diameters. Two channels of the CPSA at lower cut-off diameters of 4 and $10 \mathrm{~nm}$ were used for the present analysis. The TSI CPC was set to a lower cut-off diameter at $14 \mathrm{~nm}$. Number concentrations of ultra-fine condensation nuclei were defined as the number concentrations of particles with diameters between 4 and $10 \mathrm{~nm}$. The TSI CPC was used in combination with a thermodenuder to measure the num- ber concentration of non-volatile particles. The thermodenuder was set to a temperature of $250^{\circ} \mathrm{C}$. It was set up to evaporate volatile and low-volatile compounds like ammonium sulphate and ammonium nitrate in large parts before the sample reaches the measurement instrument (Slanina et al., 1981; Johnson et al., 2004). In the following the nomenclature of volatile particles (VOL) will be used for substances that evaporated or decomposed at $250^{\circ} \mathrm{C}$. The residual particles will be named non-volatile particles (NV).

Aerosol number size distributions were measured with optical particle spectrometers. Passive Cavity Aerosol Spectrometer Probe (PCASP-100X) (Liu et al., 1992) operated aboard both aircraft and a Forward Scattering Spectrometer Probe (FSSP-300) operated aboard the DLR Falcon 20. Both instruments were mounted outside the aircraft cabin. The nominal size range of the PCASP-100X is $0.12-3.5 \mu \mathrm{m}$ (15 channels), the size range of the FSSP-300 is $0.3-30 \mu \mathrm{m}$ (31 channels). Both PCASP-100X were compared during two intercomparison flights. The comparisons showed very good agreement in the total number concentrations and good agreement in the aerosol size spectra. PCASP-100X and FSSP-300 and their inlet systems are sensitive to pitch and roll angles of the aircraft. Optimum measurement conditions can be found during horizontal and straight flight legs. These horizontal flight legs feature suitable conditions to measure aerosol size distributions in the troposphere. In addition to the two wing-mounted probes, two Grimm Sky-OPCs model 1.129 were installed inside the cabin of the DLR Falcon 20. One Grimm Sky-OPC operated in combination with the thermodenuder allowing measurements of volatile and nonvolatile size distributions and volume concentrations. The Grimm Sky-OPC has a size range of $0.25-32 \mu \mathrm{m}$ (32 channels) according to the manufacturer. However, all instruments that were mounted inside the cabin of the DLR Falcon 20 to measure particle properties sampled the ambient air through an isokinetic inlet. This leads to a removal of large particles while sampling the air mass. The upper cutoff diameter of the inlet varies with the flight altitude. It decreases from approximately $2.5 \mu \mathrm{m}$ at ground level to $1.0 \mu \mathrm{m}$ at $10 \mathrm{~km}$ altitude (Fiebig, 2001; Hamburger, 2011).

The optical particle spectrometer probes were calibrated using monodisperse aerosol particles of various nonabsorbing substances with known refractive index. The used calibration aerosol consisted of Di-Ethyl-Hexyl-Sebacat (DEHS), polystyrene latex (PSL), ammonium sulphate and sodium chloride.

In the present analysis the following definition of aerosol particle modes is used (abbreviation and size range in brackets): ultra-fine condensation nuclei (UCN, 0.004-0.01 $\mu \mathrm{m}$ ), condensation nuclei $(\mathrm{CN},>0.01 \mu \mathrm{m})$, accumulation mode particles (ACC, $0.15-1 \mu \mathrm{m}$ ) and coarse mode particles (COA, $>1 \mu \mathrm{m})$.

All absolute concentrations in the present analyses are reported as concentrations at standard temperature $(T=$ $273.15 \mathrm{~K})$ and pressure $(p=1013.25 \mathrm{hPa})$ and are denoted 
by "stp". The analysis is solely based on measurements retrieved at cloud free conditions.

\subsection{Classification of sampled air masses using trajectory analysis}

Air mass transport analysis is an essential tool to support the interpretation of aerosol measurements with additional information of the history of the probed air masses. The transport analysis provides information on the air mass source regions, on the time scale of the air mass transport between the source region and the actual observation, or on the evolution of the meteorological conditions along the transport pathway. This information is of crucial importance for the present analysis as the link between the source regions of aerosol particles and the airborne observations could not be closed due to the practical limitations mentioned above. The trajectory analysis serves as tool to investigate aerosol ageing processes solely based on the airborne in-situ measurements. This section describes the methods used for transport analysis in the present work.

Back trajectories are calculated using the core routine of the Lagrangian Analysis Tool (LAGRANTO) developed by Wernli (Wernli and Davies, 1997; Wernli, 1997). The start points of the back trajectories are set every minute along the respective flight tracks. A box of a specified size is set up around each given start point. Within the box, an ensemble of 100 back trajectories is started to estimate the sensitivity of the trajectories. The dimensions of the box for the present analysis are set to a maximum horizontal distance of $500 \mathrm{~m}$ and a maximum vertical distance of $100 \mathrm{~m}$ to the given start point. The trajectories are calculated backwards for $96 \mathrm{~h}$ which was found to be the maximum time for an air mass passing across the region of interest, i.e. Central and Western Europe. The calculation time step is set to $30 \mathrm{~min}$. If trajectories go below the ground, i.e. where the pressure becomes larger than the surface pressure, they are lifted by $10 \mathrm{hPa}$ to continue the calculation.

The input data for the trajectory calculation is retrieved from the ECMWF operational archive (Persson and Grazzini, 2007). The horizontal resolution of the used input data is $0.5^{\circ} \times 0.5^{\circ}$. The vertical resolution is split into 91 vertical levels. Analysis data are available for a six hourly resolution at 00:00, 06:00, 12:00, 18:00 UT. Prognostic data $(+3 \mathrm{~h})$ are retrieved for 03:00, 09:00, 15:00, and 21:00 UT to provide a temporal resolution of three hours.

The resulting trajectories are used to calculate meteorological parameters along each single trajectory pathway in combination with ECMWF fields. Amongst other parameters, relative humidity and boundary layer height are used for the analysis of the present data. The boundary layer height is used to check whether ground based emissions can affect the air masses along the trajectory path way or not. Uptake of ground based emissions is defined as possible if the trajectory goes below the upper limit of the boundary layer. To reduce the bias induced by cloud-aerosol interactions only observations where the relative humidity does not exceed $80 \%$ within the last $96 \mathrm{~h}$ along the back trajectories are used. A comparison of temperature, specific humidity and boundary layer height retrieved from in-situ measurements and the ECMWF model can be found in Section A.

The EDGAR database (Emissions Database for Global Atmospheric Research) EDGARv4.1 is used to define the regional variation of the source strength of anthropogenic emissions along each trajectory. Thus, an age of the anthropogenic emissions, i.e. particles, within the observed air masses can be estimated to support the analysis of the in-situ measurements. Detailed information regarding the EDGARv4.1 database can be found on the project webpage http://edgar.jrc.ec.europa.eu/.

The EDGAR database is solely used within the present trajectory analysis to provide qualitative information of emissions for different regions and to estimate an age of the observed particles. A normalized emission factor $E_{\mathrm{N}}$ is calculated for each cell on a $0.5^{\circ} \times 0.5^{\circ}$ grid to derive a dimensionless qualitative value for the source strength of a region relative to the global emissions. Ground based anthropogenic emissions of $\mathrm{CO}, \mathrm{CO}_{2}, \mathrm{NH}_{3}, \mathrm{NO}_{\mathrm{x}}$, and $\mathrm{SO}_{2}$ are retrieved from the EDGAR database to calculate the total emission per grid cell. The emission quantities can be related to primary particle formation from combustion processes $\left(\mathrm{CO}, \mathrm{CO}_{2}\right)$ (Bond et al., 2004; McMeeking et al., 2010, 2011) or secondary particle formation through gas-to-particle conversion due to agricultural or industrial activities $\left(\mathrm{NH}_{3}, \mathrm{NO}_{\mathrm{x}}, \mathrm{SO}_{2}\right)$ (Kulmala and Kerminen, 2008; Morgan et al., 2010a).

The retrieved total emission per grid cell is normalized between the minimum of all global grid cells which are not zero and the 99th percentile of all global grid cells. The 99th percentile is used as the upper limit to reduce the effect of exceptional high emission rates on the normalization. The normalized emission factor $E_{\mathrm{N}}$ at the respective grid cell $i$ can be derived as follows:

$E_{\mathrm{G}}=\left\{x \mid x \in\left\{E_{S, 0}, \ldots, E_{S, n}\right\} \wedge x>0\right\}$,

$E_{\mathrm{P} 99}=\mathrm{P} 99\left(E_{\mathrm{G}}\right)$,

$E_{N, i}=E_{\mathrm{S}, i} / E_{\mathrm{P} 99}$

$E_{\mathrm{S}, i}$ represents the sum of the source types at grid cell $i$. $E_{\mathrm{G}}$ is the global set of all $E_{\mathrm{S}, i}$ not zero and $E_{\mathrm{P} 99}$ the 99th percentile of $E_{\mathrm{G}}$. Finally, $E_{\mathrm{N}}$ at the grid cell $i$ is derived by normalising $E_{\mathrm{S}, i}$ to $E_{\mathrm{P} 99}$. All normalized values $E_{\mathrm{N}}$ greater than 1 are set to 1 . The resulting normalized emission index $E_{\mathrm{N}}$ is mapped in Fig. 2a. $E_{\mathrm{N}}$ indicates in a quantitative way regions of different emission potential on the $0.5^{\circ} \times 0.5^{\circ}$ grid. According to the database, regions of enhanced anthropogenic emissions in Europe can be located within a band reaching from England, the Benelux States and Western Germany to South Germany and the Po Valley in Northern Italy.

The observed air masses are classified by the time between the measurement and the time of the strongest emission 
events occurring along the air mass transport pathway within the last $96 \mathrm{~h}$ before the measurement. Emissions along the trajectories are averaged over $12 \mathrm{~h}$ time intervals. Using this analysis method, measured aerosol properties can be classified with respect to the age of the dominating emissions within the respective air mass. E.g., measurements can be classified into fresh emissions of an age $0-12 \mathrm{~h}$, or rather aged emissions of an age $48-60 \mathrm{~h}$. A more accurate temporal resolution would overestimate the abilities of this trajectory analysis for a densely populated region like Europe with a vast diversity of different emission sources on a rather small scale.

\section{Results of airborne in-situ measurements}

The analysis of the data measured aboard the DLR Falcon 20 and FAAM BAe-146 aircraft is separated into different sections accounting for the spatial and temporal variations as well as the different observed quantities. Sections 3.1 and 3.3 give a general overview of the horizontal and vertical $\mathrm{CN}$ and ACC number concentrations measured aboard both aircraft within the planetary boundary layer. A discussion of measurements performed aboard the DLR Falcon 20 comprising vertical profiles of UCN, CN, and ACC number concentrations and the mixing state above certain selected regions as well as an analysis of number size distributions at different altitude levels is accomplished in Sections 3.4 and 3.5. The results of the trajectory analysis are discussed in Section 4. The trajectory analysis is combined with both, measurements performed aboard the DLR Falcon 20 and FAAM BAe-146. Exceptions are mentioned in the text.

\subsection{The horizontal distribution of $\mathrm{CN}$ and accumulation mode number concentrations}

Figures $2 \mathrm{~b}$ and $\mathrm{c}$ respectively show the average horizontal distributions of $\mathrm{CN}$ and ACC number concentrations observed during the EUCAARI-LONGREX campaign in May 2008. The number concentrations are averaged on a $0.5^{\circ} \times 0.5^{\circ}$ grid. Only measurements within the planetary boundary layer are used to relate the observations to ground based emissions. The boundary layer height was taken from the ECMWF operational archive to distinguish between insitu measurements inside and outside the planetary boundary layer. The grey arrow indicates in both figures the main air mass transport pathway during the measurements.

Increased $\mathrm{CN}$ number concentrations which were observed inside the planetary boundary layer can be associated with recent particle formation events and thus indicate regions rich in particle sources. An agglomeration of relatively high average $\mathrm{CN}$ number concentrations exceeding 7000 particles $\mathrm{cm}^{-3}$ stp and reaching up to 20000 particles $\mathrm{cm}^{-3}$ stp were observed above the Benelux States, Central and South Germany, and Eastern Germany

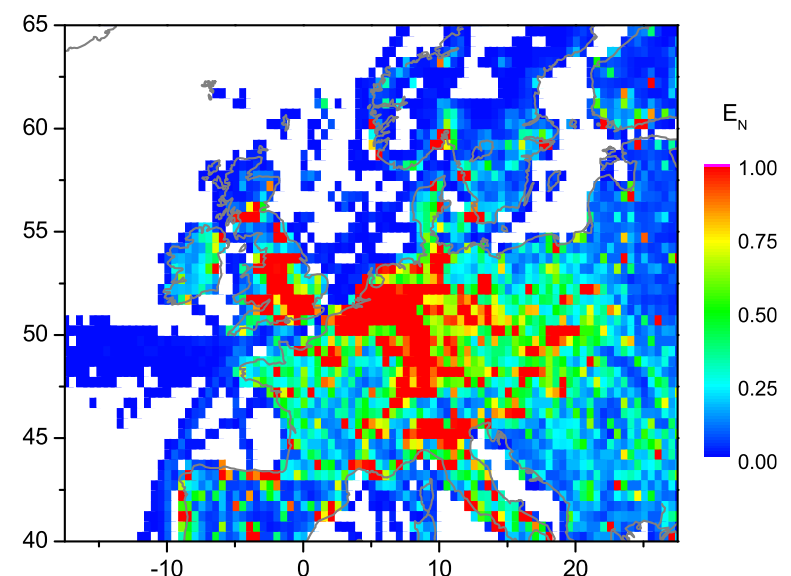

(a)

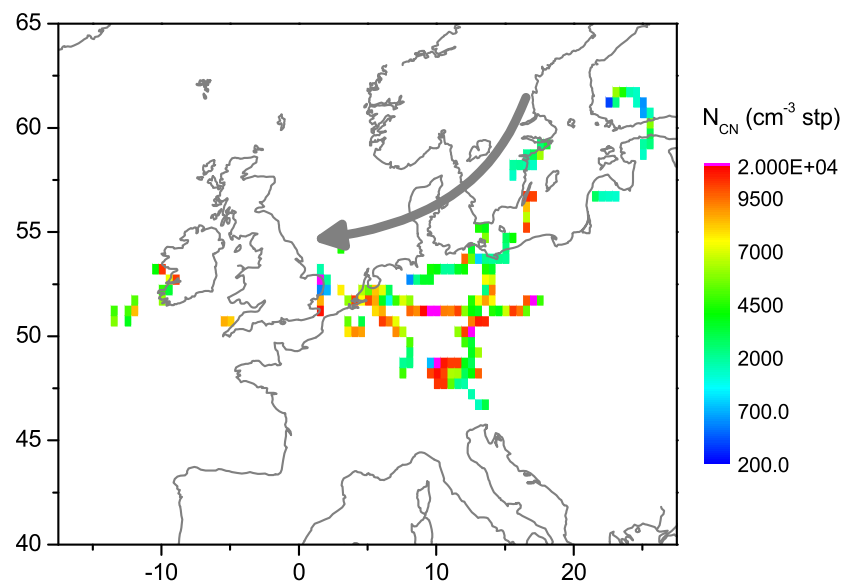

(b)

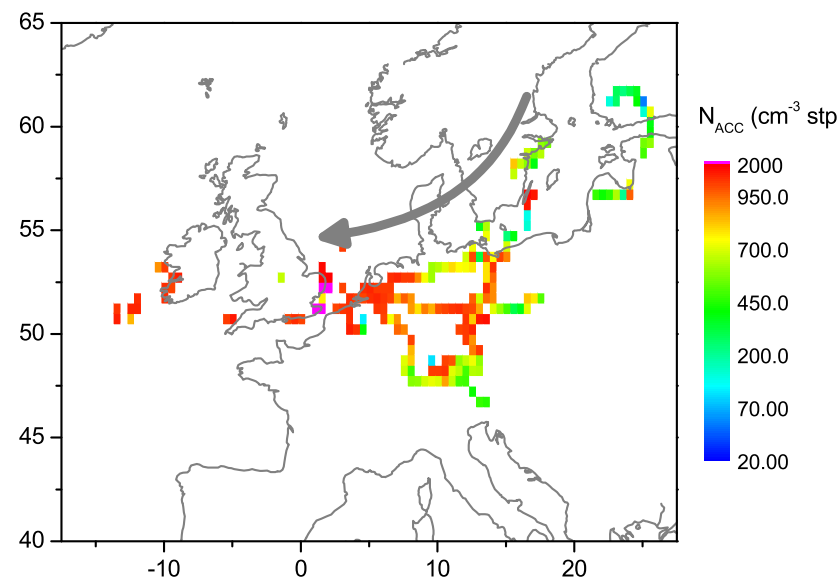

(c)

Fig. 2. Normalized emission factor $E_{\mathrm{N}}$ (a) based on the EDGARv4.1 emission database (http://edgar.jrc.ec.europa.eu/) and horizontal distributions of $\mathrm{CN}$ (b) and ACC (c) number concentrations within the boundary layer derived from DLR Falcon 20 and FAAM BAe-146 measurements. Average values are given for a $0.5^{\circ} \times 0.5^{\circ}$ grid. The grey arrow $(\mathbf{b}, \mathbf{c})$ indicates the main air mass transport direction. Please note the logarithmic colour scale for the particle number concentrations. 


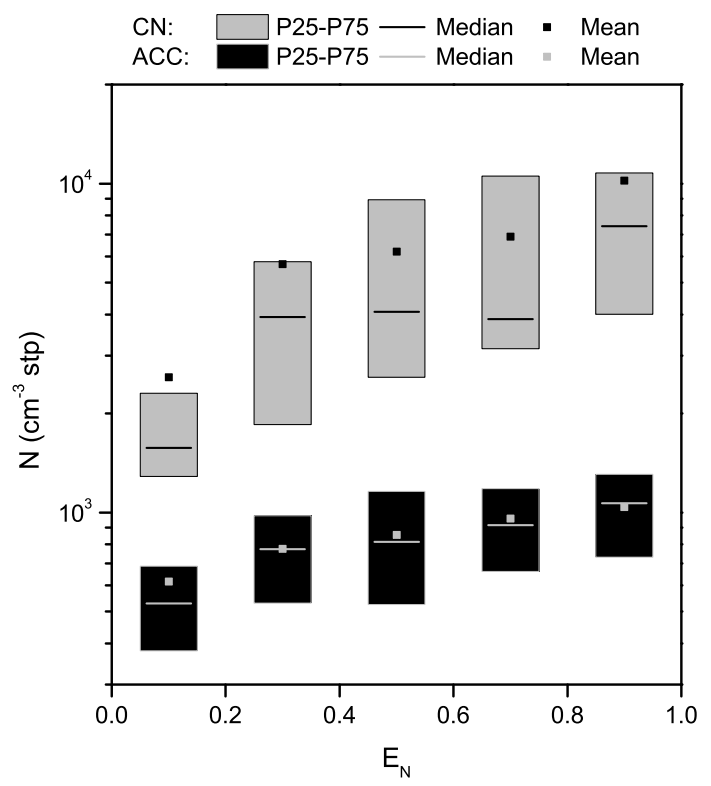

Fig. 3. Comparison of the normalized emission factor $E_{\mathrm{N}}$ with measured CN (grey) and ACC (black) number concentrations (see Figure 2). The bars show the 1st and 3rd quartiles (lower and upper column limits) and the median (centre line) for $0.2 E_{\mathrm{N}}$ bins.

and Western Poland, i.e. above continental regions. Further events of high $\mathrm{CN}$ number concentrations were observed on the coast lines of Ireland, the south-east of England and Öland in the Baltic Sea. Number concentrations below 7000 particles $\mathrm{cm}^{-3}$ stp were observed above the south of Finland, the south-east of Sweden, North Germany, and the Atlantic south-west of Ireland. However, the measurements of $\mathrm{CN}$ number concentrations exhibit high variability with an average standard deviation of $40 \%$ per grid cell.

The average standard deviation per grid cell of ACC number concentrations is $20 \%$ and accounts for less spatial and temporal variability of ACC particles compared to $\mathrm{CN}$. An increase of accumulation mode particles indicates a coagulation of aerosol particles with preceding time and possible uptake of gaseous and particulate emissions by pre-existing particles. The observed pattern of ACC number concentrations shows an increase of number concentrations following the main air mass transport pathway during the anticyclonic conditions from the south of Finland $\left(\sim 200 \mathrm{~cm}^{-3} \mathrm{stp}\right)$ and the north-east of Germany $\left(\sim 700 \mathrm{~cm}^{-3} \mathrm{stp}\right)$ to the Benelux States and the south-east of England reaching 10002000 particles $\mathrm{cm}^{-3}$ stp. Increased ACC number concentrations were also observed above Eastern and Central Germany, the region west of Munich, Germany and downwind the air mass transport pathway south-west of Ireland.

\subsection{Comparison of the normalized emission index $E_{N}$ with observations}

The airborne measurements within the planetary boundary layer allow for a direct comparison of the observations with the normalized emission index $E_{\mathrm{N}}$. Figure 3 compares the $\mathrm{CN}$ and $\mathrm{ACC}$ number concentrations measured aboard both aircraft to $E_{\mathrm{N}}$. The figures show the mean, median and 1st and 3rd quartiles (P25, P75) of number concentrations at standard temperature and pressure per $0.2 E_{\mathrm{N}}$ bin.

The median of the $\mathrm{CN}$ number concentrations increase with increasing $E_{N}$, i.e. increasing emission intensity, from $1600-7400 \mathrm{~cm}^{-3}$ stp. However, the high deviation between the quartiles and median concentrations of up to $170 \%$ per $E_{\mathrm{N}}$ bin illustrates the high spatial and temporal variability of $\mathrm{CN}$ number concentrations observed during aircraft measurements.

The median ACC number concentrations increase almost constantly between $E_{\mathrm{N}} 0-1$ from $530-1100 \mathrm{~cm}^{-3}$ stp. The deviations between the quartiles and the median number concentrations vary between 20-40\%. The comparison of the observed number concentrations with the emission index $E_{\mathrm{N}}$ indicates that the accumulation mode is more appropriate for a comparison of ground based emissions with airborne measurements due to the relatively longer lifetime of ACC particles compared to $\mathrm{CN}$ particles. $\mathrm{CN}$ number concentrations are more sensitive for spatial and temporal variations of the measurement location as they occur during airborne measurements. In contrast, ACC particles are spatially and temporally less variable (Williams et al., 2002).

\subsection{Zonal means of the vertical aerosol distribution}

Vertical profiles of $\mathrm{CN}$ and $\mathrm{ACC}$ number concentrations were binned into vertical levels of $500 \mathrm{~m}$ depth up to $5 \mathrm{~km}$ altitude and zonal means with a resolution of $5^{\circ}$ were calculated for each altitude bin (Fig. 4). Please note the average latitude of the measurements which increases from West to East from $52^{\circ} \mathrm{N}$ to $60^{\circ} \mathrm{N}$.

Maximum $\mathrm{CN}$ number concentrations of more than $7000 \mathrm{~cm}^{-3}$ stp were observed mainly below $1 \mathrm{~km}$ altitude between $10^{\circ} \mathrm{W}-15^{\circ} \mathrm{E}$, i.e. from Ireland to Eastern Germany. Number concentrations decreased eastwards where measurements were conducted dominantly north of $55^{\circ} \mathrm{N}$. The number concentrations decreased above $1 \mathrm{~km}$ altitude and averaged at $2000-3000 \mathrm{~cm}^{-3}$ stp between $1-1.5 \mathrm{~km}$.

Increased ACC number concentrations of 1000$2000 \mathrm{~cm}^{-3} \mathrm{stp}$ occurred already from $15^{\circ} \mathrm{W}$, i.e. above the Atlantic south-west of Ireland, and reached till $15^{\circ} \mathrm{E}$. High ACC number concentrations were also observed above $1 \mathrm{~km}$ altitude and reached $2 \mathrm{~km}$ altitude in contrast to the maxima of $\mathrm{CN}$ number concentrations that were limited to $1 \mathrm{~km}$ altitude. 


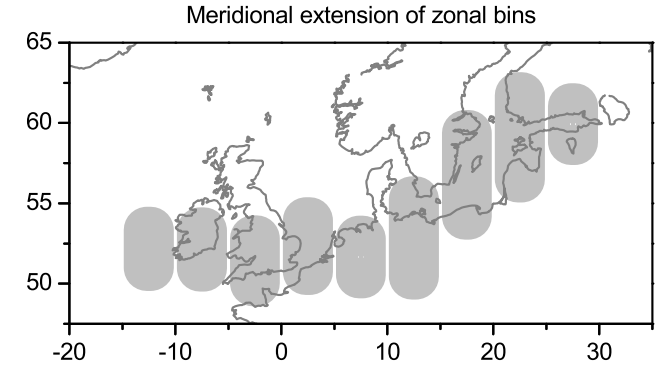

(a)

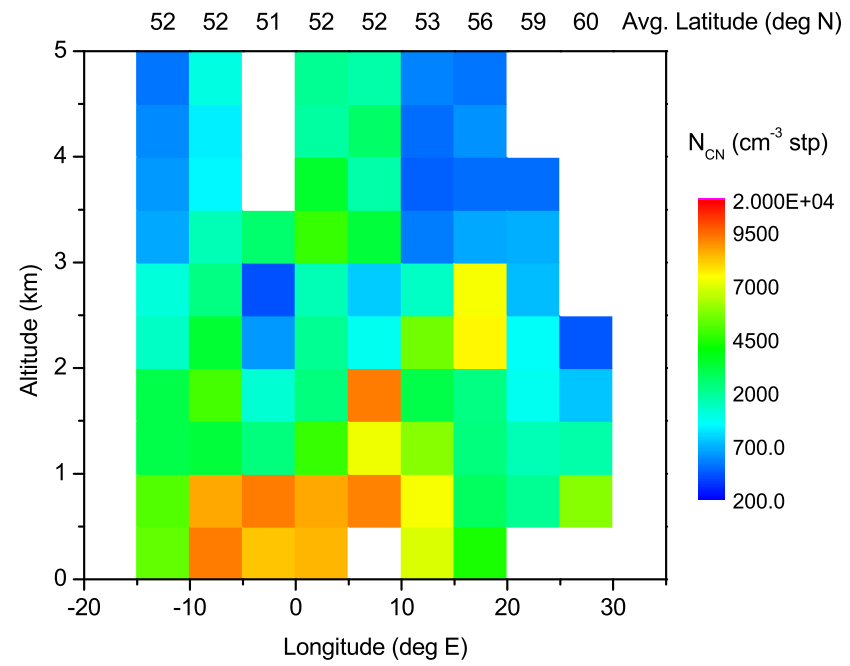

(b)

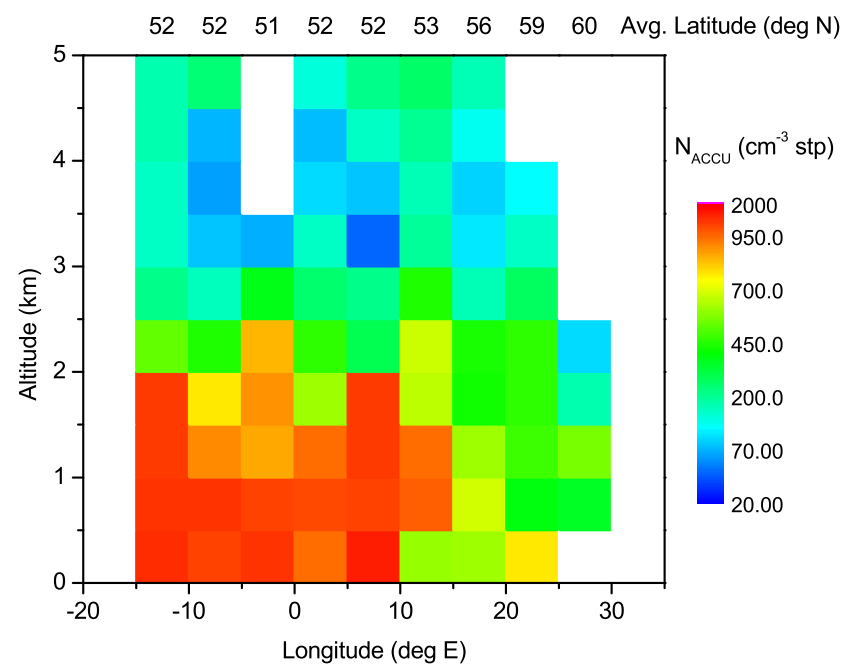

(c)

Fig. 4. Zonal distribution of binned vertical profiles (a) of $\mathrm{CN}$ (b) and ACC (c) number concentrations North of $50^{\circ} \mathrm{N}$ derived from DLR Falcon 20 and FAAM BAe-146 measurements. Please note the variable average latitude of the measurements and the logarithmic colour scale.

\subsection{Aerosol microphysical properties above selected regions in Europe}

In the present section vertical profiles measured aboard the DLR Falcon 20 aircraft are analysed. Statistics of vertical bins with a depth of $250 \mathrm{~m}$ each were calculated for several number concentrations. However, the extensive dataset measured during the vertical profiles covered a large horizontal area on a continental scale and a time span exceeding the lifetime of typical synoptic events. Thus, a simple averaging of all data, although binned into several vertical levels, would lead to a loss of useful information. Therefore, the vertical profiles were split into four different regions: the northeast of Germany and the Baltic Sea, the Benelux States, Ireland, and South Germany (see Fig. 1). The measured data were also separated into the two synoptic periods which occurred during the EUCAARI-LONGREX campaign in May 2008. Thus, the effects of the meteorological situation on the aerosol population can be considered. Most notably this is important for the region of South Germany as the cyclones occurring during period (b) mainly affected Southern and Central Europe.

Figure 5 shows the vertical profiles measured above the north-east of Germany and the Baltic Sea, the Benelux States, Ireland, and South Germany, sorted from top to bottom. The profiles show number concentrations of UCN $\left(N_{\mathrm{UCN}}\right), \mathrm{CN}\left(N_{\mathrm{CN}}\right), \mathrm{ACC}\left(N_{\mathrm{ACC}}\right)$, and $\mathrm{NV}\left(N_{\mathrm{NV}}\right)$. In addition the number ratio of non-volatile particles $\left(R_{\mathrm{N}(\mathrm{NV} / \mathrm{CN})}\right)$ and the volume ratio of volatile matter to the total aerosol volume for particles in diameter smaller than $2.5 \mu \mathrm{m}$ $R_{\mathrm{V}\left(\mathrm{VOL} / \mathrm{PM}_{2.5}\right)}$ are plotted. Median, 10th and 90th percentiles of the respective number concentrations $N_{\mathrm{UCN}}, N_{\mathrm{CN}}, N_{\mathrm{ACC}}$, and $N_{\mathrm{NV}}$ were calculated for $1.5 \mathrm{~km}$ vertical bins below $3 \mathrm{~km}$ altitude and $3 \mathrm{~km}$ vertical bins above $3 \mathrm{~km}$. They illustrate the absolute variability of the respective number concentrations observed in the atmosphere and are listed in Table 2.

\subsubsection{Vertical aerosol distribution north of $50^{\circ} \mathrm{N}$ above the continent}

The most significant difference between period (a) and period (b) above the regions of the north-east of Germany and the Baltic Sea and the Benelux States was found to be the number concentration of UCN close to the surface layer. $N_{\mathrm{UCN}}$ reached 5800 and 20000 particles $\mathrm{cm}^{-3}$ stp within the lowest $500 \mathrm{~m}$ above the respective regions during period (a). The number concentrations reached the lower detection limit during period (b) in the boundary layer. Hardly any events of occurring UCN particles were observed within the lower free troposphere. UCN particles were observed again in the upper free troposphere between $8-10 \mathrm{~km}$ above the north-east of Germany and the Baltic Sea during period (b).

The high abundance of UCN close to the surface is reflected in the maximum number concentrations of $\mathrm{CN}$ reaching $21000 \mathrm{~cm}^{-3}$ stp in the boundary layer above the Benelux 

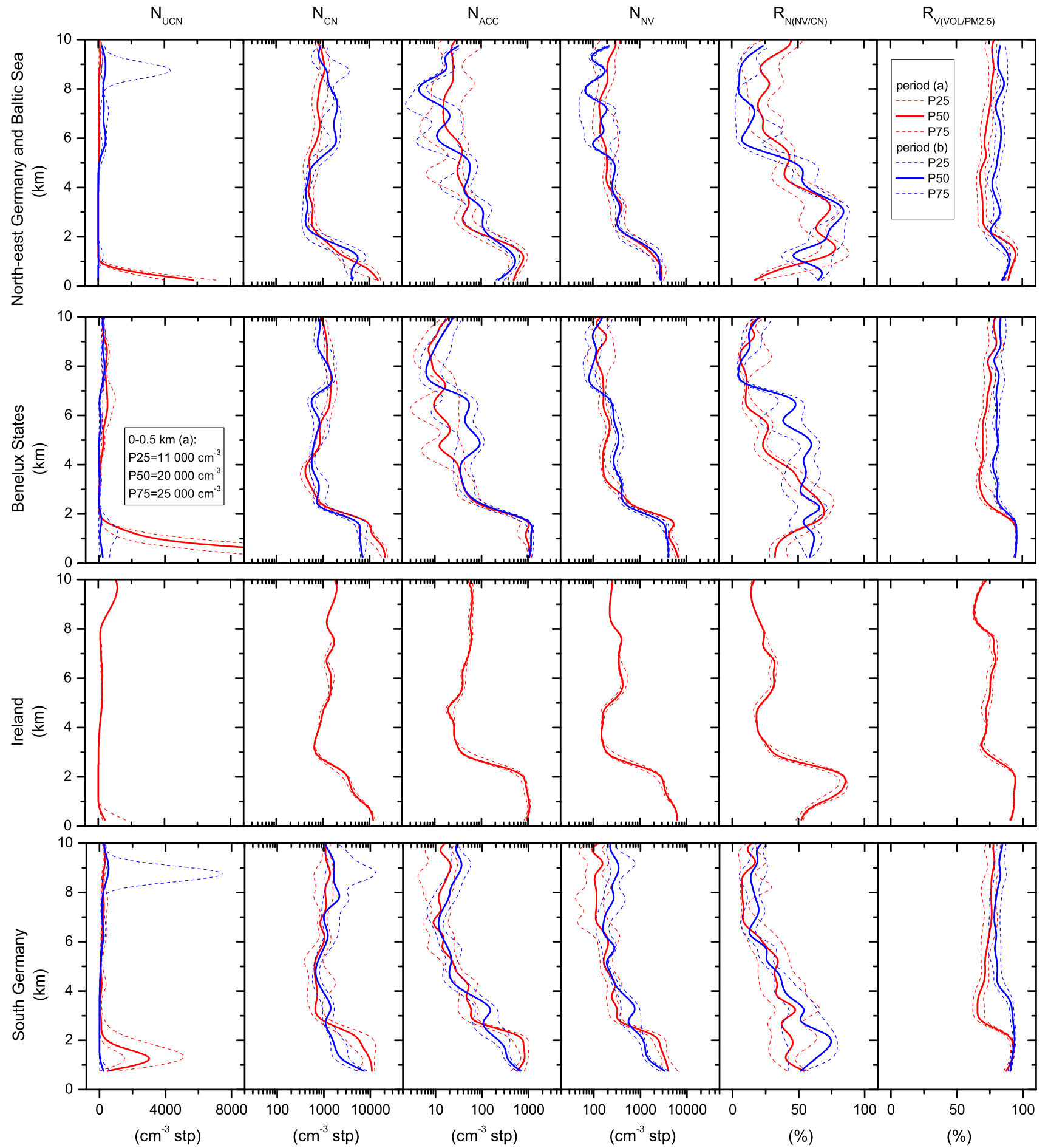

Fig. 5. Vertical profiles of number concentration of particles in diameter $D_{\mathrm{P}} 0.004-0.01 \mu \mathrm{m} N_{\mathrm{UCN}}, \mathrm{D}_{\mathrm{P}}>0.01 \mu \mathrm{m} N_{\mathrm{CN}}, \mathrm{D}_{\mathrm{P}} 0.15-1.0 \mu \mathrm{m}$ $N_{\mathrm{ACC}}$, and particles containing a non-volatile core $N_{\mathrm{NV}}\left(250^{\circ} \mathrm{C}\right)$. All number concentrations are reported in particles $\mathrm{cm}^{-3}$ at standard temperature and pressure (stp). In addition, number fractions of non-volatile particles $\mathrm{R}_{\mathrm{N}} \mathrm{NV} / \mathrm{CN}$ and volume ratios of volatile matter $\mathrm{R}_{\mathrm{V}}$ VOL/PM2.5 are given in \%. The red (blue) line shows values for the period between 1-15 (16-31) May, i.e. period (a) and (b). Each vertical profile contains median and 1 st and 3 rd quartiles. 
Table 2. Absolute number concentrations of UCN particles $\left(N_{\mathrm{UCN}}, 0.004 \mu \mathrm{m}<\mathrm{D}_{\mathrm{P}}<0.01 \mu \mathrm{m}\right)$, CN particles $\left(N_{\mathrm{CN}}, \mathrm{D}_{\mathrm{P}}>0.01 \mu \mathrm{m}\right)$, accumulation mode particles $\left(N_{\mathrm{ACC}}, \mathrm{D}_{\mathrm{P}}>0.15 \mu \mathrm{m}\right)$, and non-volatile particles $\left(N_{\mathrm{NV}}, \mathrm{D}_{\mathrm{P}}>0.014 \mu \mathrm{m}, 250^{\circ} \mathrm{C}\right)$ in $\mathrm{cm}^{-3} \mathrm{stp}$. All concentrations are given at standard pressure and temperature. The 10th (P10), 50th (P50, i.e. median), and 90th (P90) percentile are given for each vertical bin above the respective region for each value.

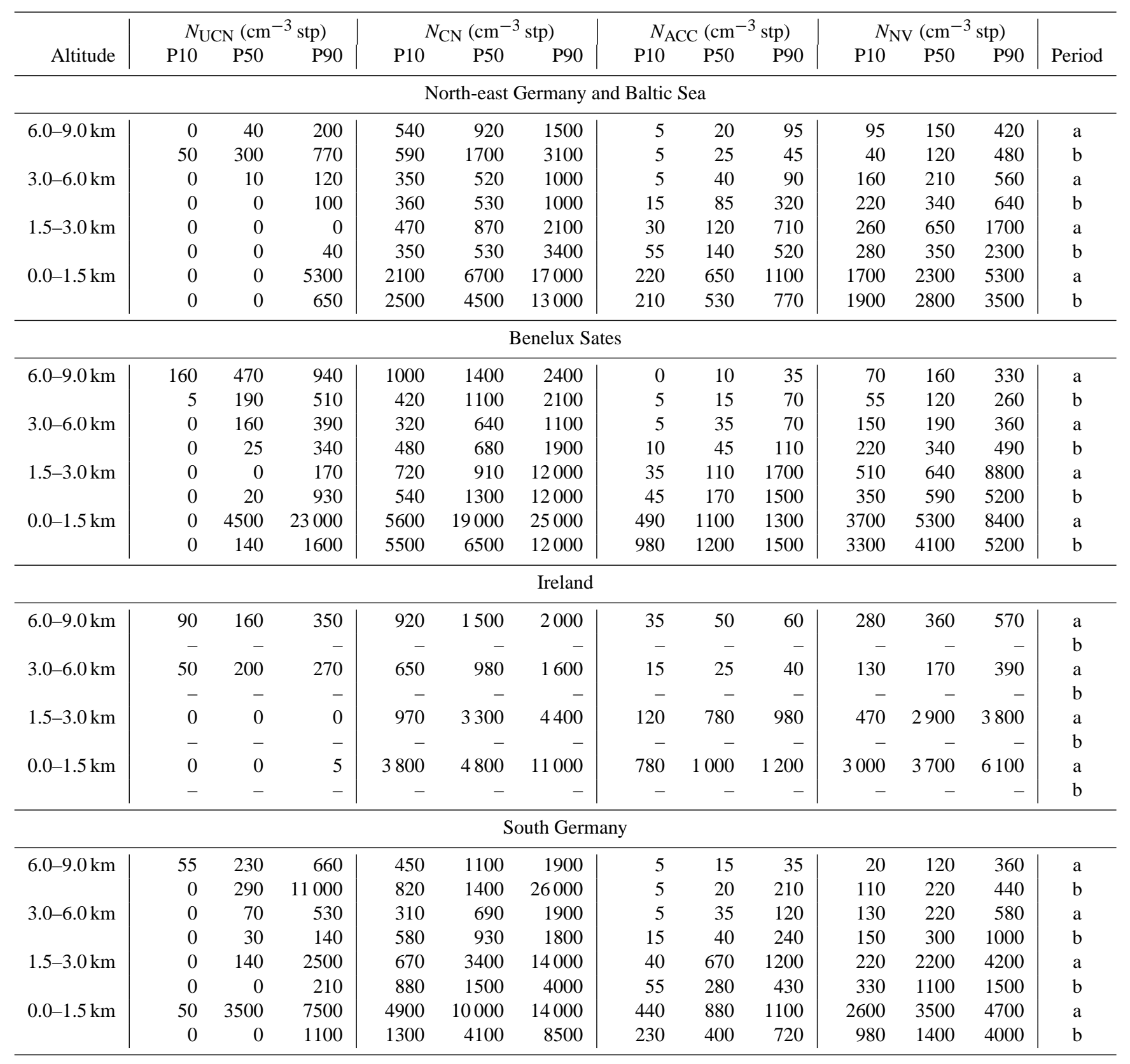

States during period (a). Strong negative gradients of number concentrations at the transition between the boundary layer and the free troposphere were observed for $\mathrm{CN}, \mathrm{ACC}$ and $\mathrm{NV}$ particles. The number concentrations dropped during period (a) from 19000 to $910 \mathrm{~cm}^{-3} \operatorname{stp}\left(N_{\mathrm{CN}}\right), 1100$ to $110 \mathrm{~cm}^{-3} \mathrm{stp}$ $\left(N_{\mathrm{ACC}}\right)$, and 5300 to $640 \mathrm{~cm}^{-3}$ stp $\left(N_{\mathrm{NV}}\right)$ by one order of magnitude between the boundary layer and the free troposphere.
$\mathrm{CN}$ number concentrations during period (a) exceeded $\mathrm{CN}$ number concentrations during period (b) by a factor 2-2.5 within the boundary layer above the north-east of Germany and the Baltic Sea and the Benelux States. However, $N_{\mathrm{ACC}}$ and $N_{\mathrm{NV}}$ show only little variance between the two meteorological periods and differ by a factor 1-1.5 within the boundary layer. 
In contrast to the stable conditions during period (a), enhanced vertical mixing between the boundary layer and the lower free troposphere occurred during period (b). The vertical mixing during period (b) was enabled by less vertical stability of the troposphere and frontal uplift. $N_{\text {ACC }}$ increases from period (a) to period (b) by a factor $\sim 1.5$ to $\sim 50 \mathrm{~cm}^{-3}$ stp between an altitude of $4-7 \mathrm{~km}$ above the Benelux States. The ratio of volatile volume to the total volume $R_{\mathrm{V}\left(\mathrm{VOL} / \mathrm{PM}_{2.5}\right)}$ reached similar values of $\sim 93 \%$ above both regions for both periods within the boundary layer. Above the boundary layer $R_{\mathrm{V}\left(\mathrm{VOL} / \mathrm{PM}_{2.5}\right)}$ averaged at $76 \%$ during period (a) and $83 \%$ during period (b).

The number fraction of non-volatile particles $R_{\mathrm{N}(\mathrm{NV} / \mathrm{CN})}$ exhibits high variability throughout the troposphere. Within the lowest $500 \mathrm{~m}$ close to the emission sources $R_{\mathrm{N}(\mathrm{NV} / \mathrm{CN})}$ reached 17 (32)\% during period (a) and 66 (59) \% during period (b) above the north-east of Germany and the Baltic Sea (the Benelux States). Maximum ratios up to $87 \%$ of particles containing a non-volatile core were found above the north-east of Germany and the Baltic Sea between approximately $1-4 \mathrm{~km}$. They exceed the maximum ratios $R_{\mathrm{N}(\mathrm{NV} / \mathrm{CN})}$ located downwind of the north-east of Germany above the Benelux States which reached $70 \%$ at $\sim 2 \mathrm{~km}$ altitude.

\subsubsection{Aged continental pollution layer above the Atlantic}

Air masses originating from Central Europe were transported towards the British Isles, Ireland and the western part of the North Atlantic following the main air mass transport direction during the anticyclonic conditions during period (a). Measurement flights were conducted on the south-western coastline of Ireland and off the coast above the Atlantic. The flights were planned according to air mass transport simulations using the FLEXPART model (Stohl et al., 2005). The predicted pollution layers were detected below $3 \mathrm{~km}$ altitude above the open sea.

Only a few events of increased UCN could be observed downwind the continental emission sources above Ireland and the Atlantic. High $\mathrm{CN}$ number concentrations were found in the marine boundary layer $\left(12000 \mathrm{~cm}^{-3} \mathrm{stp}\right)$ and in the elevated pollution layers $\left(4800 \mathrm{~cm}^{-3}\right.$ stp at 0 $1.5 \mathrm{~km}$ and $3300 \mathrm{~cm}^{-3}$ stp at $1.5-3 \mathrm{~km}$ ). The pollution layers were clearly differentiated from the lower free troposphere which was defined by a minimum number concentrations of $600 \mathrm{~cm}^{-3}$ stp at $3 \mathrm{~km}$ altitude and above. Median values of $N_{\text {ACC }}$ averaged at $980 \mathrm{~cm}^{-3}$ stp below $2 \mathrm{~km}$ and decreased to $\sim 30 \mathrm{~cm}^{-3}$ stp between $3-5 \mathrm{~km}$. The ratio $R_{\mathrm{N}(\mathrm{NV} / \mathrm{CN})}$ had its maximum at $\sim 2 \mathrm{~km}$ altitude and reached values up to $100 \%$ inside distinct pollution layer. $R_{\mathrm{V}}\left(\mathrm{VOL} / \mathrm{PM}_{2.5}\right)$ averaged at $93 \%$ within the pollution which gives a similar value compared to the continental regions discussed above.

\subsubsection{The effect of different meteorological conditions on the vertical aerosol distribution}

The most continuous measurements of vertical profiles were conducted above the region of South Germany. Hence, a detailed comparison between both meteorological periods can be obtained from the respective flights over this region. In addition, Southern Europe was strongly affected by frontal passages during the second half of May 2008 due to cyclones passing over the Mediterranean and UCN particles could be observed in the cloud outflow at high altitudes indicating preceding new particle formation.

Increased concentrations of UCN particles were measured inside the boundary layer during period (a) and the upper free troposphere between $8-10 \mathrm{~km}$ during period (b) comparable to the region above the north-east of Germany and the Baltic Sea (see Fig. 5). CN number concentrations followed a $\mathrm{C}$-shaped vertical profile with maximum number concentrations of $11000 \mathrm{~cm}^{-3}$ stp measured within the lowest $500 \mathrm{~m}$, a minimum of $620 \mathrm{~cm}^{-3}$ stp in the mid-troposphere at approximately $5 \mathrm{~km}$ and a local maximum of $1500 \mathrm{~cm}^{-3} \mathrm{stp}$ in the upper troposphere at approximately $8.5 \mathrm{~km}$.

The largest variations between both meteorological periods were observed between $1.5-3 \mathrm{~km}$ altitude. The number concentrations of $\mathrm{CN}, \mathrm{ACC}$ and $\mathrm{NV}$ during period (a) exceeded the respective number concentrations during period (b) by a factor $2-2.5$ between $1.5-3 \mathrm{~km}$. This feature is also reflected by the vertical decrease of number concentrations with altitude. Whereas number concentrations were rather uniform throughout the boundary layer and dropped by an order of magnitude at the transition to the free troposphere during period (a), number concentrations decreased continuously from the surface level to the respective minimum in the free troposphere during period (b). In contrast to the decreasing number concentrations at low altitudes, the number concentrations at high altitudes increased from period (a) to period (b) by a factor $1.3-1.8$ above $6-7 \mathrm{~km}$.

No significant variance was observed for $R_{\mathrm{V}}\left(\mathrm{VOL} / \mathrm{PM}_{2.5}\right)$ below $2 \mathrm{~km}$. $R_{\mathrm{V}\left(\mathrm{VOL} / \mathrm{PM}_{2.5}\right)}$ averaged at $92 \%$ here. The vertical profile of $R_{\mathrm{V}\left(\mathrm{VOL} / \mathrm{PM}_{2.5}\right)}$ during period (a) was characterised by a strong decrease above $\sim 2 \mathrm{~km}$ reaching its minimum of $65 \%$ at $3 \mathrm{~km}$. In contrast, $R_{\mathrm{V}\left(\mathrm{VOL} / \mathrm{PM}_{2.5}\right)}$ remained constant up to an altitude of $\sim 4 \mathrm{~km}$ during period (b) and decreased to $81 \%$ above. I.e. relatively more secondary volatile matter was transported to higher altitudes in the lower troposphere during period (b) than during the much more stable conditions in period (a).

\subsection{Size distributions retrieved from airborne measurements above Europe}

The aerosol size distributions discussed in the following are based on the following vertical classification.

The C-shaped vertical profiles of total number concentrations suggest a classification into three layers as the 
Table 3. Number of flight legs (FL) and altitude range of the layers $(\mathrm{km})$ used for the classification of the horizontal flight legs.

\begin{tabular}{rrr}
\hline Layer & \# FL & Alt (km a.s.1.) \\
\hline UFT & 25 & $5.5-10.0$ \\
LFT & 27 & $2.1-7.0$ \\
DL & 12 & $1.0-3.9$ \\
BL & 22 & $0.2-1.8$ \\
\hline
\end{tabular}

observations in the previous Sect. 3.4 already indicated. The lowest layer covers the boundary layer and shows maximum aerosol number concentrations and high average relative humidity $(\overline{\mathrm{RH}}=55 \%$ between $0-3 \mathrm{~km}$, with $\overline{\mathrm{RH}}$ being the arithmetic mean of the relative humidity within the given altitude range) during the anticyclonic conditions. A mid layer above the boundary layer shows minimum aerosol number concentrations and relatively dry conditions $(\overline{\mathrm{RH}}=15 \%$ between $3-6 \mathrm{~km})$. The upper layer exhibits increasing total number concentrations and increasing relative humidity compared to the mid layer $(\overline{\mathrm{RH}}=35 \%$ between $6-9 \mathrm{~km})$. Each horizontal flight leg was analysed within the respective vertical profile of aerosol properties and meteorological conditions which were observed with the aircraft and classified into one of the following vertical layers: boundary layer (BL), lower free troposphere (LFT) and upper free troposphere (UFT). Several horizontal flight legs were performed inside stable layers right above the boundary layer showing high aerosol load and significantly different meteorological conditions than the LFT. These layers, clearly decoupled from the boundary layer, were classified as decoupled layers (DL). Table 3 shows the number of flight legs and altitude range of each defined layer.

The size distributions obtained by PCASP-100X and FSSP-300 measurements were first averaged for each horizontal flight leg. A log-normal number size distribution in the accumulation and coarse mode size range was fitted to each of the averaged size distributions. The fitted size distributions were classified into the respective vertical layer. Figure 6 shows the median and quartiles of each group of fitted size distributions. The respective average modal fitting parameters separated into BL/DL, LFT and UFT are listed in Table 4.

Following the main air mass transport direction the average ACC number concentration within BL/DL increased from the north-east of Germany $\left(860 \mathrm{~cm}^{-3} \mathrm{stp}\right)$ towards the Benelux States $\left(2000 \mathrm{~cm}^{-3} \mathrm{stp}\right)$ and decreased again during transport to Ireland $\left(1600 \mathrm{~cm}^{-3} \mathrm{stp}\right)$. The average count median diameter $\overline{\mathrm{CMD}}$ and geometric standard deviation $\overline{\mathrm{GSD}}$ remained similar and averaged at $0.2 \mu \mathrm{m}$ and 1.5 , respectively. The average number concentration of observed coarse mode particles (COA) decreased from the Baltic Sea towards the Atlantic from 1.4 to $0.64 \mathrm{~cm}^{-3}$ stp whereas the $\overline{\mathrm{CMD}}$ increased from 1.4 to $2.3 \mu \mathrm{m}$.

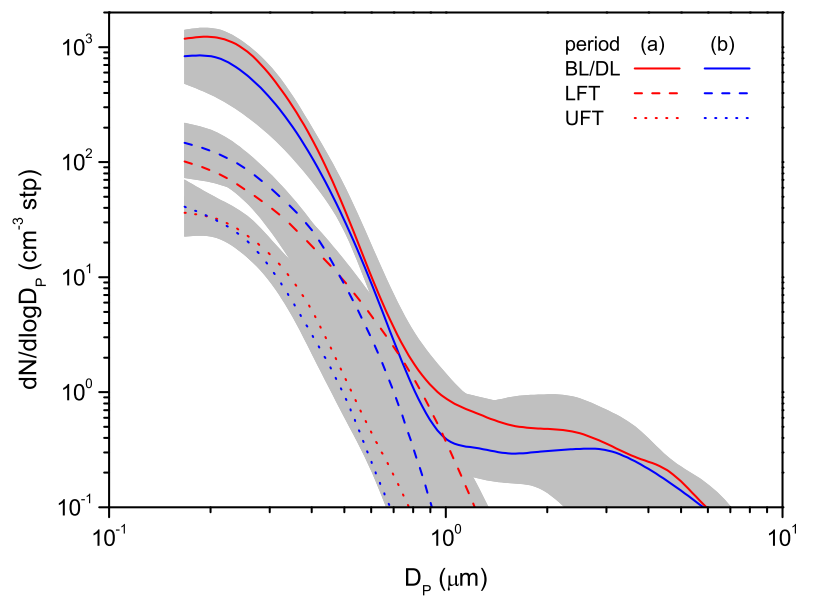

(a)

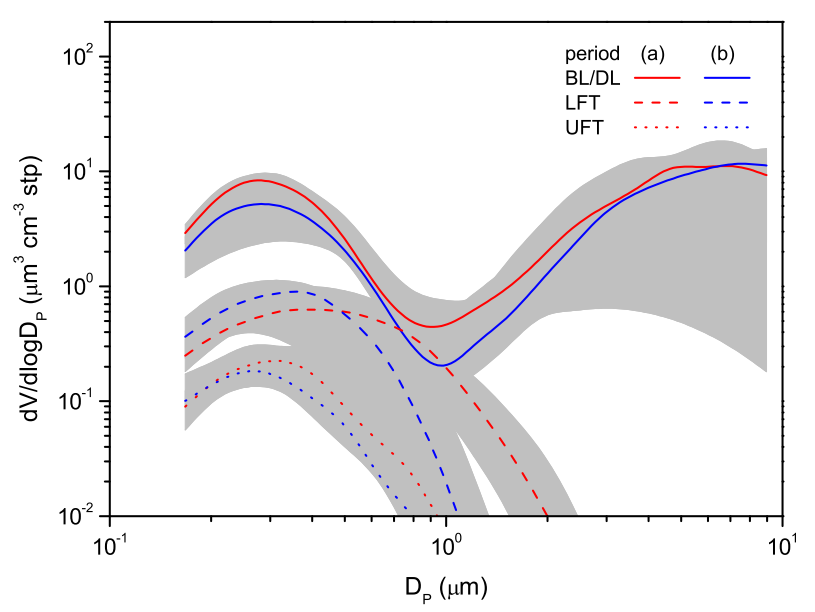

(b)

Fig. 6. Number size distributions (a) and volume size distributions (b) above all regions. Concentrations are given at standard temperature and pressure. The panels show measurements performed during horizontal flight legs within the boundary layer and decoupled layers (BL/DL), the lower free troposphere (LFT) and upper free troposphere (UFT). The red and blue lines show median values for periods (a) and (b), respectively. The grey shade indicates the 1st and 3rd quartiles.

The average ACC number concentration varied within the LFT between $30-230 \mathrm{~cm}^{-3}$ stp and in the UFT between 40 $65 \mathrm{~cm}^{-3}$ stp. The minimum of $\overline{\mathrm{CMD}}$ for the accumulation mode was observed above South Germany within the LFT during period (b) reaching $0.14 \mu \mathrm{m}$. The average $\overline{\mathrm{CMD}}$ in the UFT was $0.17 \mu \mathrm{m}$.

No significant occurrence of coarse mode particles was observed above the BL/DL at cloud free conditions. The bulk of the aerosol volume and aerosol mass is limited to the boundary layer (Fig. 6b). A clear tendency towards lower total aerosol mass appears for the 1st quartile of coarse mode particles during period (b) in the BL/DL indicating scavenging of coarse particles during period (b). Larger particles 
Table 4. Modal fitting parameter for size distributions selected by regions and vertical levels. The corresponding size distributions are shown in Fig. 6. Average number concentrations $\overline{\mathrm{N}}$ are given in particles $\mathrm{cm}^{-3}$ at standard temperature and pressure and average count median diameter $\overline{\mathrm{CMD}}$ in $\mu \mathrm{m}$.

\begin{tabular}{|c|c|c|c|c|c|c|}
\hline Layer & $\overline{\mathrm{N}}$ & $\frac{\mathrm{ACC}}{\mathrm{CMD}}$ & $\overline{\mathrm{GSD}}$ & $\overline{\mathrm{N}}$ & $\frac{\mathrm{COA}}{\mathrm{CMD}}$ & $\overline{\mathrm{GSD}}$ \\
\hline \multicolumn{7}{|c|}{ North-east Germany and Baltic Sea } \\
\hline UFT & 61 & 0.17 & 1.6 & - & - & - \\
\hline LFT & 230 & 0.17 & 1.6 & - & - & - \\
\hline BL/DL & 860 & 0.20 & 1.5 & 1.4 & 1.4 & 2.1 \\
\hline \multicolumn{7}{|c|}{ Benelux States } \\
\hline UFT & 44 & 0.17 & 1.6 & - & - & - \\
\hline LFT & 180 & 0.15 & 1.7 & - & - & - \\
\hline $\mathrm{BL} / \mathrm{DL}$ & 2000 & 0.20 & 1.4 & 0.79 & 1.6 & 1.9 \\
\hline \multicolumn{7}{|c|}{ Ireland } \\
\hline UFT & 65 & 0.16 & 1.5 & - & - & - \\
\hline$*$ LFT & 30 & 0.19 & 1.5 & - & - & - \\
\hline BL/DL & 1600 & 0.19 & 1.5 & 0.64 & 2.3 & 1.8 \\
\hline \multicolumn{7}{|c|}{ South Germany, period (a) } \\
\hline UFT & 40 & 0.17 & 1.6 & - & - & - \\
\hline LFT & 110 & 0.16 & 1.7 & - & - & - \\
\hline BL/DL & 1500 & 0.16 & 1.5 & 0.3 & 2.5 & 2.2 \\
\hline \multicolumn{7}{|c|}{ South Germany, period (b) } \\
\hline UFT & - & - & - & - & - & - \\
\hline LFT & 84 & 0.14 & 1.6 & - & - & - \\
\hline${ }^{*} \mathrm{BL} / \mathrm{DL}$ & 370 & 0.19 & 1.5 & - & - & - \\
\hline
\end{tabular}

*: only one single event

were more present within the LFT and UFT during period (a) while smaller particles occurred during period (b). This indicates that the meteorological conditions for particle growth were more favourable during period (a).

\section{Application of the trajectory analysis to the observations}

The trajectory analysis described above was applied to all horizontal flight legs performed by the FAAM BAe-146 and DLR Falcon 20. The flight legs were classified by the time interval along the back trajectories that featured the dominating, i.e. strongest, average normalized emission intensity $E_{\mathrm{N}}$ within the last $96 \mathrm{~h}$. Thus, the measurements can be analysed with respect to the age of the emissions. This gives the possibility to discuss the observations within the scope of aerosol ageing processes. The analysis of aerosol ageing processes at non-cloud conditions also benefits from the stable synoptic conditions and the prevailing high pressure conditions. Nevertheless, only flight legs where the relative humidity did not

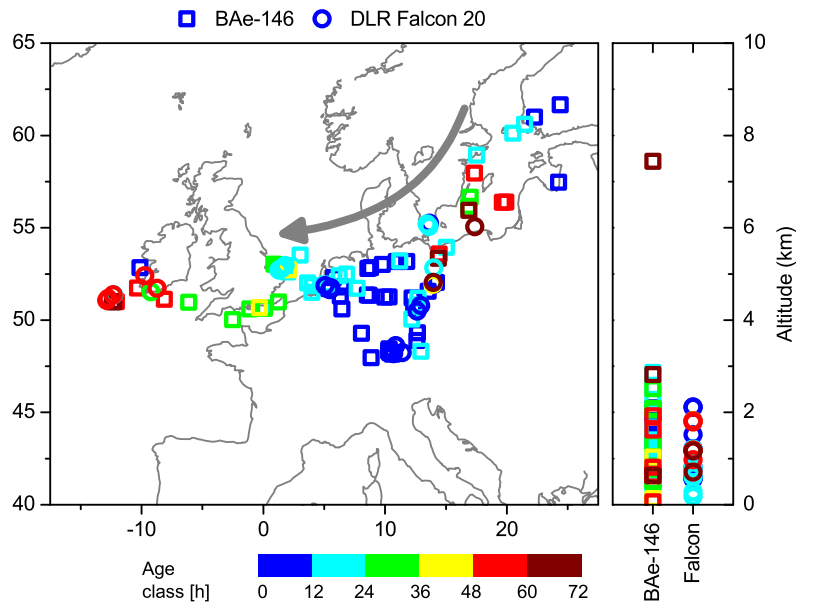

Fig. 7. Horizontal and vertical distribution of flight legs classified into different age classes using trajectory analysis. The arrow depicts the main air mass transport direction during the anticyclonic conditions. For detailed information see text.

exceed $80 \%$ within the last $96 \mathrm{~h}$ were used to reduce the bias induced by cloud-aerosol interactions. Air masses that were not in contact to the maritime or continental boundary layer within the last $96 \mathrm{~h}$ according to the trajectory analysis were omitted.

Figure 7 shows the horizontal and vertical distribution of the age classes retrieved from the trajectory analysis. Following the air mass transport pathway from south-west of Finland to the south of the Baltic Sea, the age classes increase from fresh emissions of an age $0-12 \mathrm{~h}$ to rather aged emission of an age $>60 \mathrm{~h}$. The aged emissions were partly transported inland reaching the larger area of Berlin. Uptake of fresh emissions happened again above Germany and the Benelux States. Emissions of an age of 24-36 h dominated the probed air masses above the English Channel. Further downstream off the south-west Coast of Ireland the dominating age class was $48-60 \mathrm{~h}$. Almost all classified horizontal flight legs meeting the requirements (cloud free conditions and contact to the boundary layer within the last $96 \mathrm{~h}$ ) were located below $3 \mathrm{~km}$ altitude as convection was suppressed by the high pressure conditions.

To retrieve intensive quantities, ratios of selected number and volume concentrations to total concentrations are used for the analysis of aerosol ageing processes instead of absolute numbers. Hence, bias produced by varying source strength can be avoided. Statistics were calculated for every age class for the ratio of accumulation mode particles to the total $\mathrm{CN}$ number concentration $R_{\mathrm{N}(\mathrm{ACC} / \mathrm{CN})}$, the ratio of non-volatile particles to the total $\mathrm{CN}$ number concentration $R_{\mathrm{N}(\mathrm{NV} / \mathrm{CN})}$, and the ratio of volatile matter to the total volume concentration of $\mathrm{PM}_{2.5} R_{\mathrm{V}\left(\mathrm{VOL} / \mathrm{PM}_{2.5}\right)}$ (Fig. 8).

$R_{\mathrm{N}(\mathrm{ACC} / \mathrm{CN})}$ comprises measurements of DLR Falcon 20 and FAAM BAe-146. Its average values increase with the age of the dominating emissions from $21 \%$ at $0-12 \mathrm{~h}$ to $44 \%$ 


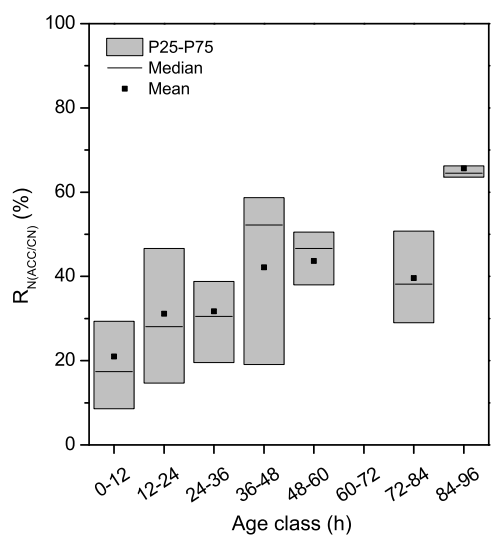

(a)

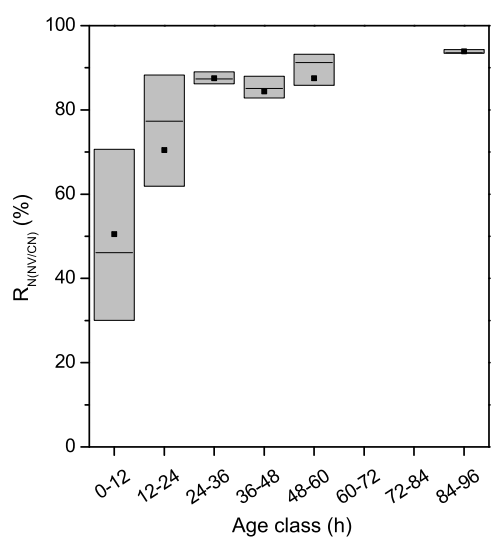

(b)

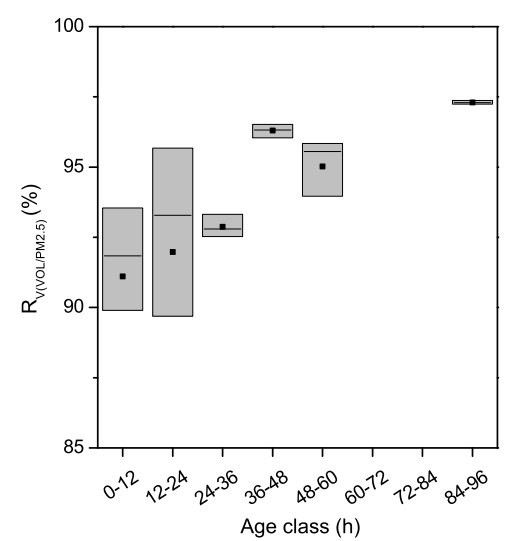

(c)

Fig. 8. Classification of measurements into time intervals of the maximum contribution of emissions along the air mass transport pathway within in the last $120 \mathrm{~h}$. (a) shows the ratio of accumulation mode particles to total number concentration, (b) the ratio of non volatile particles to total number concentration and (c) the ratio of the volatile aerosol volume to the total aerosol volume. Median, mean and 1 st and 3rd quartiles (P25, P75) are given.

at $48-60 \mathrm{~h}$. An exceptionally high ratio of $66 \%$ is reached for the age class $84-96 \mathrm{~h}$. However, only one flight leg was classified into this age class. The standard deviations vary for all other age classes between $15-22 \%$.

The ratios $R_{\mathrm{N}(\mathrm{NV} / \mathrm{CN})}$ and $R_{\mathrm{V}\left(\mathrm{VOL} / \mathrm{PM}_{2.5}\right)}$ were obtained solely from DLR Falcon 20 measurements. No horizontal flight legs were classified into the age classes $60-72 \mathrm{~h}$ and $72-84 \mathrm{~h}$. Only one flight leg was classified into each of the age classes $24-36 \mathrm{~h}, 36-48 \mathrm{~h}$ and $84-96 \mathrm{~h}$. Hence, the data has to be treated with care. However, it has to be noted that each dataset represents a flight leg of $50-100 \mathrm{~km}$ in horizontal distance and that approximately 500 trajectories were started from each flight leg to retrieve the required information for the classification.

The ratio of particles containing a non-volatile core $R_{\mathrm{N}(\mathrm{NV} / \mathrm{CN})}$ increases with age. For the age class $0-12 \mathrm{~h}$ the $R_{\mathrm{N}(\mathrm{NV} / \mathrm{CN})}$ averages at $51 \%$ with a standard deviation of $20 \%$. The average increases with emission age up to $88 \%$ (24-36 h) and reaches $94 \%$ at 84-96 h. Increasing ratios can also be found for $R_{\mathrm{V}\left(\mathrm{VOL} / \mathrm{PM}_{2.5}\right)}$ from $91 \%(0-12 \mathrm{~h})$ to $96 \%$ (36-48 h). Again the largest standard deviations occur for age classes $0-12 \mathrm{~h}$ and $12-24 \mathrm{~h}(\sim 40 \%)$, i.e. for rather fresh emissions.

\section{Discussion}

The dataset of aerosol microphysical properties presented in this paper gives an overview of aerosol properties within the whole tropospheric column above Europe. It provides observational evidence of aerosol ageing processes and the analysis of the aerosol properties during different stages of the aerosol lifecycle.
The obtained tropospheric aerosol properties are consistent with data obtained during previous campaigns and recent studies (see Table 5). Ground based long-term observations at the continental measurement site close to Melpitz, Germany, give all-season averages of size resolved aerosol number concentrations (Birmili et al., 2001; Engler et al., 2007). The number concentrations used for the comparison were retrieved from fitting parameters of log-normal size distributions and calculated for the respective size ranges of $\mathrm{UCN}$, $\mathrm{CN}$ and ACC particles (see Section 2.2). In large part the number concentrations of ground based measurements fall into the same range as the number concentrations probed by the aircraft in the boundary layer. The $\mathrm{CN}$ number concentrations observed above the Benelux States and South Germany however outnumber the long-term ground-based averages. This underlines the exceptionally high particle number concentration within the boundary layer induced by the stable synoptic conditions during period (a). Similar high $\mathrm{CN}$ number concentrations reaching $20000 \mathrm{~cm}^{-3}$ stp in the BL were observed during airborne aerosol measurements by Petzold et al. (2002) south-east of Berlin, Germany. However, the reported number concentrations vary by an order of magnitude.

The changing meteorological conditions between period (a) and period (b) resulted in a change of the particle load due to an exchange of air masses during frontal passages. However, the change in atmospheric stability caused a change in vertical mixing of pollutants linked to the surface, too. High UCN number concentrations indicating nucleation events were most frequently observed inside the boundary layer during the dry period (a). In contrast, wet scavenging and convection during period (b) reduced the entrapment of possible aerosol precursors close to the surface and within the boundary layer and inhibited their accumulation. 
Table 5. Comparison of number concentrations observed during the EUCAARI-LONGREX field campaign with number concentrations reported in literature. All number concentrations are reported in $\mathrm{cm}^{-3}$ stp. Italic characters indicate ground based measurements, airborne measurements are indicated with non-italic characters.

\begin{tabular}{llll}
\hline $\begin{array}{l}\text { Atmospheric } \\
\text { Layer }\end{array}$ & Parameter & $\begin{array}{l}\text { EUCAARI- } \\
\text { LONGREX }\end{array}$ & Literature \\
\hline UFT & $N_{\mathrm{UCN}}$ & $40-470$ & $1400^{\mathrm{a}}, 1000^{\mathrm{b}}$ \\
& $N_{\mathrm{CN}}$ & $920-1700$ & $770^{\mathrm{a}}, 580-1200^{\mathrm{c}, *}$ \\
& $N_{\mathrm{ACC}}$ & $10-50$ & $40^{\mathrm{a}}, 10-100^{\mathrm{c}, *}$ \\
& $N_{\mathrm{NV}}$ & $120-220$ & $100^{\mathrm{a}}$ \\
& $N_{\mathrm{UCN}}$ & $0-200$ & $20^{\mathrm{b}}, 5-8^{\mathrm{d}, *}$ \\
& $N_{\mathrm{CN}}$ & $520-980$ & $390-1100^{\mathrm{c}, *}, 360-1000^{\mathrm{d}, *}, 540^{\mathrm{e}, *}$ \\
& $N_{\mathrm{ACC}}$ & $25-85$ & $20-80^{\mathrm{c}, *}, 22-92^{\mathrm{d}, *}, 18^{\mathrm{e}, *}$ \\
$\mathrm{BL} / \mathrm{DL}$ & $N_{\mathrm{NV}}$ & $170-340$ & $100^{\mathrm{a}}$ \\
& $N_{\mathrm{UCN}}$ & $0-4500$ & $330^{\mathrm{f}, *}, 160-330^{\mathrm{g}, *}$ \\
& $N_{\mathrm{CN}}$ & $4100-19000$ & $2700-20000^{\mathrm{c}, *}, 4500-7800^{\mathrm{f}, *}, 4900-8900^{\mathrm{g}, *}$ \\
& $N_{\mathrm{ACC}}$ & $400-1200$ & $70-560^{\mathrm{c}, *}, 600-1200^{\mathrm{f}, *}, 950-1900^{\mathrm{g}, *}$ \\
& $N_{\mathrm{NV}}$ & $1400-5300$ & $2700-5400^{\mathrm{g}, *}$ \\
\hline
\end{tabular}

a: Minikin et al. (2003), North-western Europe, September/October, NV at $250^{\circ} \mathrm{C}$

b: Schröder et al. (2002), Central Europe, July/August, ${ }^{\text {c }}$ : Petzold et al. (2002), Central Europe, July/August

d: Venzac et al. (2009), Western Europe, winter, ${ }^{e}$ : Asmi et al. (2011), Central Europe, all-season

f: Birmili et al. (2001), Central Europe, all-season, $\mathrm{g}$ : Engler et al. (2007), Central Europe, all-season, $\mathrm{NV}$ at $300^{\circ} \mathrm{C}$

*: number concentrations are calculated from log-normal size distributions to match the present particle diameter range

In contrast, destabilisation and convection increased the ratio of volatile matter within the lower free troposphere above the boundary layer.

Observations reported from the mountain sites Puy de Dôme (1 $465 \mathrm{~m}$ a.s.l.), France (Venzac et al., 2009) and Jungfraujoch (3 $580 \mathrm{~m}$ a.s.l.), Switzerland (Asmi et al., 2011) provide comparison values within the lower free troposphere. Observations at Puy de Dôme were limited to the winter season to reduce possible influence of boundary layer air. In addition, airborne measurements (Petzold et al., 2002; Schröder et al., 2002) are listed in Table 5. Again the observations made during the EUCAARI-LONGREX campaign are consistent with the range of number concentrations given in literature. Remarkably, $N_{\mathrm{UCN}}$ exhibits very low median number concentrations indicating a negligible amount of nucleation events in the lower free troposphere during both periods (a) and (b). However, a pronounced negative gradient of nucleation events between the boundary layer and the lower free troposphere was observed especially during period (a). A similar result was obtained from airborne measurements during the contemporaneous IMPACT campaign which took place in the Netherlands within the EUCAARI project (Crumeyrolle et al., 2010). Also recent work by Boulon et al. (2011) has shown that nucleation events did not reach beyond the boundary layer within the lower troposphere.

The present analysis and airborne measurements presented by Minikin et al. (2003) and Mirme et al. (2010) extend the in-situ observations of UCN to the lower and upper free troposphere where nucleation events appeared. Above $8 \mathrm{~km}$ gasto-particle conversion was inhibited within the lower free tro- posphere due to subsiding air masses during period (a) and only few nucleation events were indicated at high altitudes. The vertical profile gets inverted for period (b). Hardly any nucleation events occurred at low altitudes whereas an increased number concentration of UCN particles could be observed above $8 \mathrm{~km}$. Updrafts during frontal passages and a destabilisation of the atmosphere due to the dissolving high pressure system lead to a transport of ground based emissions and aerosol precursor gases into the upper free troposphere. In addition, aircraft emissions within the highly frequented air space serve as possible particle sources in the upper troposphere (Schröder et al., 1998; Petzold et al., 1999; Singh et al., 2002; Voigt et al., 2010). Secondary aerosol showed an increase of number concentrations at high altitudes, whereas primary non-volatile particles featured a minimum above $8 \mathrm{~km}$.

Please note the high variability of the particle number concentrations reported in literature and the present analysis. The number concentrations vary by up to an order of magnitude within all altitude layers. This is especially the case for $\mathrm{UCN}$ and $\mathrm{CN}$ particles. The high spatial and temporal variability is caused by a vast diversity of aerosol sources as well as the evolution of the particle properties on a time scale of hours and days which is mainly controlled by the prevailing meteorological conditions.

The anticyclonic transport pathway during period (a) and partly during period (b) enabled aerosol measurements within different stages of the aerosol lifecycle during cloud free conditions. Accumulation mode number concentrations and the ratio of volatile volume at low altitudes were lowest over the north-east of Germany and the Baltic Sea 
compared to South Germany and the Benelux States during anticyclonic flow patterns. This indicates less influence of secondary particle matter originating from anthropogenic sources due to the continuous north-easterly flow which advected rather clean air masses from Scandinavia. The air masses continued on a pathway across Germany and the Benelux States, one of the main source regions of anthropogenic aerosol particles in Europe (Van Dingenen et al., 2004; Putaud et al., 2004, 2010). The detailed analysis of the regional differences in chemical composition by Morgan et al. (2010a) showed that the ratio between nitrate and sulphate changed from the Baltic Sea towards the Benelux States. While sulphate mass concentrations exceed the mass concentrations of nitrate within the region of the Baltic Sea and Germany, nitrate mass concentrations increase and exceed the sulphate concentrations over the Benelux States. The high sulphate mass concentrations can be related to regions dominated by industry. In contrast, nitrate compounds frequently occur above regions with intense agricultural land use and the use of fertilizer e.g. the Benelux States.

Following the uptake of anthropogenic emissions the air masses were transported across the North Sea towards the British Isles and the Atlantic coast south-west of Ireland. Back trajectory calculations showed that emissions located in the south of England only partly contributed to the particle load within the probed air masses. The air masses remained mainly unaffected by additional emissions and cloud processes. Thus, ageing of aerosol particles could be observed. The available measuring methods presented in this work enable the analysis of aerosol ageing processes based on coagulation of particles and condensation of precursor gases on pre-existing particles. Both processes caused an almost entirely internal mixing state with ratios up to $100 \%$ of particles containing a non-volatile core after $48-60 \mathrm{~h}$. The ratio of volatile volume increased to $95 \%$ and indicates a high load of secondary aerosol condensed on the particles. Morgan et al. (2010a) reported that the highest mass fraction of nonrefractory aerosol was observed to be organic aerosol with a relative mass fraction of $20-50 \%$. Organic aerosol undergoes a more dynamic chemical evolution with time compared to the relatively static nature of sulphate aerosol particles. Most organic aerosol evolves due to oxidation to oxygenated organic aerosol (Jimenez et al., 2009). Aged oxygenated lowvolatile organic matter reached $50-65 \%$ of the total organic matter close to the aerosol source regions in May 2008 and increased to $60-80 \%$ in the far field outflow like it could be observed south-west of Ireland (Morgan et al., 2010a).

The observed chemical ageing of organic matter by Morgan et al. (2010a) agrees with our trajectory analysis which shows that most cases of aged emissions were observed outside the region of Central Europe. The trajectory analysis showed that increasing number ratios of accumulation mode particles and non-volatile particles or an increase of the volume ratio of volatile matter indicates ageing of aerosol particles through coagulation and condensation. The strongest increase occurs within the first $36-48 \mathrm{~h}$ which implies a turnover time of the respective aerosol processes of approximately two days. This finding is in agreement with typical aerosol lifetimes of $\sim 48 \mathrm{~h}$ within the boundary layer (Williams et al., 2002; Riemer et al., 2004). Only trajectories where the relative humidity did not exceed $80 \%$ within the last $96 \mathrm{~h}$ were selected to avoid cloud processes. Those relatively dry air masses occurred dominantly during the high pressure situation when air masses tended to descend on a synoptic scale rather than to rise. As a consequence, it was mostly flight legs below $3 \mathrm{~km}$ altitude that could be connected to ground based emission sources and consequently were selected for the present trajectory analysis method. Thus, almost no cases of uplifted emissions could be included into the analysis.

The dry and stable meteorological conditions in the first half of May 2008 not only allowed an increase of aerosol lifetime but also an increase of the particle load within the planetary boundary layer. The vertical profiles in Section 3.4 illustrate the distinct negative gradient in number concentrations between the boundary layer and the lower free troposphere. Thus, a large fraction of the column aerosol optical depth (AOD) in the troposphere might be related to the aerosol emissions and the subsequent particle growth within the boundary layer. Considering the accumulation mode particles as the optically active fraction in the submicron diameter range for visible sunlight according to the Mie scattering theory, we can use the vertical profiles of accumulation mode particles as an indicator for the relative contribution of the boundary layer and the free troposphere to the finemode (i.e. submicron) AOD. The fraction of accumulation mode particles within the boundary layer relative to the total column reached $81-89 \%$ during the anticyclonic conditions with lowest values above the Baltic Sea and highest values above the Benelux States. The observed boundary layer height was between $2-2.5 \mathrm{~km}$ above ground level. The fraction of accumulation mode particles decreased during period (b) to $41-80 \%$ with a decreasing boundary layer height (1.5$2 \mathrm{~km}$ a.g.l.). Number concentrations of coarse mode particles were close to the detection limit within the free troposphere during cloud free conditions. Hence, estimates of a relative fraction of coarse mode particles between boundary layer and free troposphere cannot be done to extend the procedure to the total AOD. However, even though the coarse mode particles in the boundary layer contributed to a large fraction to the total aerosol volume $(\sim 50 \%)$, they contributed to a rather small fraction of $\sim 8 \%$ to the total aerosol surface. The total aerosol surface, being a main parameter of the bulk aerosol optical properties (Brock et al., 1993), was dominated by the accumulation mode. 


\section{Conclusions}

We provide with this paper a comprehensive data set of aerosol microphysical properties within the whole tropospheric column above Central Europe. The data was retrieved by airborne in-situ measurements in May 2008. The analysis of the data was divided into several regions and two distinct synoptic situations. Total aerosol number concentrations were $4100-19000 \mathrm{~cm}^{-3}$ stp in the boundary layer, $520-980 \mathrm{~cm}^{-3}$ stp in the lower free troposphere, and 920$1700 \mathrm{~cm}^{-3}$ stp in the upper free troposphere. Maximum particle concentrations were observed inside the boundary layer above the Benelux States. Number concentrations of nonvolatile particles varied in the boundary layer between 1400$5300 \mathrm{~cm}^{-3}$ stp and in the free troposphere between 120$340 \mathrm{~cm}^{-3}$ stp.

Nucleation events were indicated inside the continental boundary layer during high pressure conditions which inhibited the mixing of ground based emissions into the free troposphere. Particle nucleation ceased in the boundary layer after the high pressure system dissolved. Therefore, nucleation events occurred in the upper troposphere above $8 \mathrm{~km}$ due to the updraft of aerosol precursors and favourable conditions for nucleation events close to the cloud outflow region.

Coagulation and condensation processes were measured and analysed using trajectory analysis. The trajectory analysis showed that the number ratio of accumulation mode particles increased within the first $48 \mathrm{~h}$ from 20 to $40 \%$. The ratio of particles containing a non-volatile core increased within the same time period from 50 to $85 \%$ and indicated a transition from an external to an internal mixing state with increasing age. The main coagulation process was found to cease after two days.

The measured data is suitable for studying aerosol ageing processes unaffected by cloud-aerosol interactions and the influence of different synoptic situations on aerosol microphysical properties. The data set supports aerosol models with information throughout the whole tropospheric column (e.g. Reddington et al., 2011). However, the timespan of the measurements covers only one month, May 2008. Thus, although a comprehensive spatial data set of aerosol properties was made available, data retrieved from comparable insitu measurements which cover seasonal variations are still missing for the European continent. Knowledge of the temporal variability of aerosol properties in the whole tropospheric column is essential for improved understanding of the climatic effects of tropospheric aerosol particles. Thus, further airborne in-situ measurements combined with ground or satellite based remote sensing observations are of great value.

\section{Appendix A}

\section{Comparison of meteorological model data with in-situ measurements}

Suitable analysis of meteorological parameters alongside the calculated trajectories requires the verification of key parameters retrieved from the ECMWF model. During the aircraft field campaign meteorological parameters such as temperature and specific humidity were measured aboard the FAAM BAe-146 and DLR Falcon 20. Both aircraft measure temperature with a Rosemount temperature sensor and the specific humidity with a Lyman-Alpha absorption hygrometer. These parameters can be used to compare in-situ measurements with model data.

Figure A1 (a) and (b) show the comparison of temperature and specific humidity for FAAM BAe-146 and DLR Falcon 20, respectively. Linear regression of the compared data showed high correlation for all parameters. The correlation coefficient for the comparison of model data and FAAM BAe-146 data was 0.97 for temperature and 0.96 for specific humidity. Correlation coefficients of 1.0 and 0.97 result from the comparison of model data with DLR Falcon 20 data for temperature and specific humidity, respectively.

The major parameter used for the analysis of the contribution of ground-based sources along a trajectory is the boundary layer height retrieved from the ECMWF. The boundary layer height is parameterised by the ECMWF using the parcel lifting method (or bulk Richardson method) proposed by Troen and Mahrt (1986). Trajectories are only considered as influenced by ground based sources if the air masses pass through the boundary layer, i.e. the trajectory altitude is lower than the boundary layer height. All punctures of the DLR Falcon 20 through the boundary layer top were identified to compare the model boundary layer height with the observed one. The boundary layer top was identified using vertical temperature, humidity and aerosol concentration profiles as well as vertical profiles measured with the LIDAR aboard the DLR Falcon 20.

Figure A2 shows the boundary layer heights retrieved from in-situ measurements and the ECMWF. While comparing the boundary layer heights one must consider several problems that might lead to deviation. Firstly, the ECMWF delivers the boundary layer height as the height of the mixing layer that is in contact to the surface. In contrast, it can appear that the top of the boundary layer identified from in-situ measurements can be the top of the uppermost layer amongst others showing similar properties and no significant separation. Secondly, the boundary layer height strongly depends on the nature of the surface and can show a high spatial variability above a heterogeneous surface such as that of Central Europe. The specifics of the surface govern the heat and humidity transfer from the surface into the boundary layer and thus its stability and capability of increasing depth. The average boundary layer height on a $0.5^{\circ} \times 0.5^{\circ}$ grid which results in 

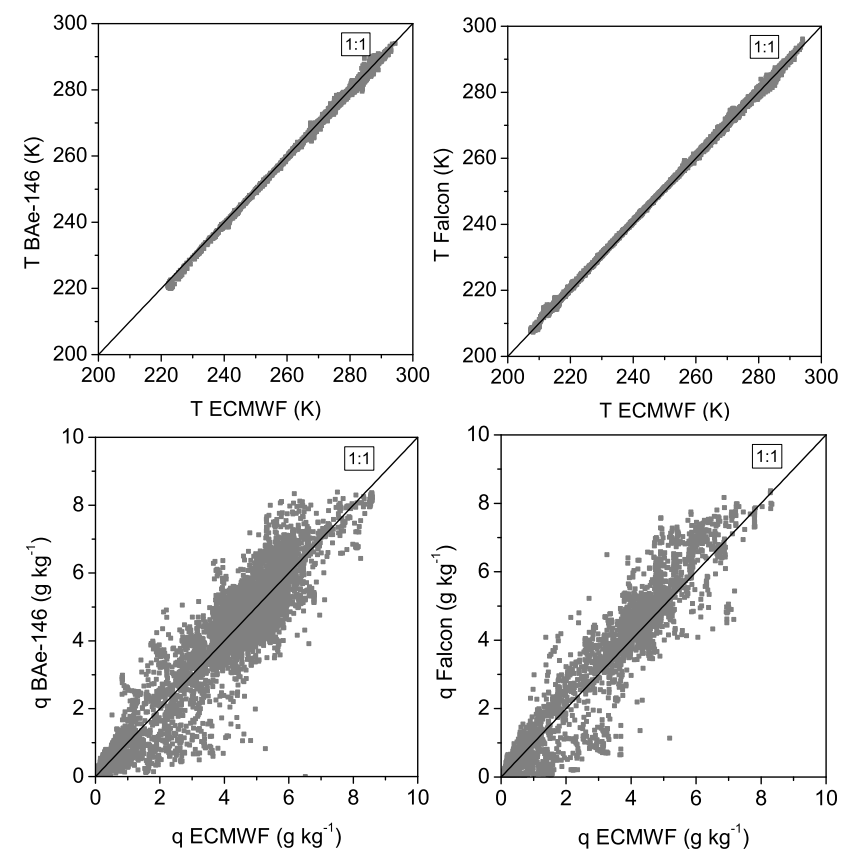

Fig. A1. Comparison of temperature $T(\mathrm{~K})$ (a) and specific humidity $\mathrm{q}\left(\mathrm{g} \mathrm{kg}^{-1}\right)$ (b) from in-situ measurements of FAAM BAe-146 (left panels) and DLR Falcon 20 (right panels) with ECMWF model analysis data. The black line denotes the 1:1 line.

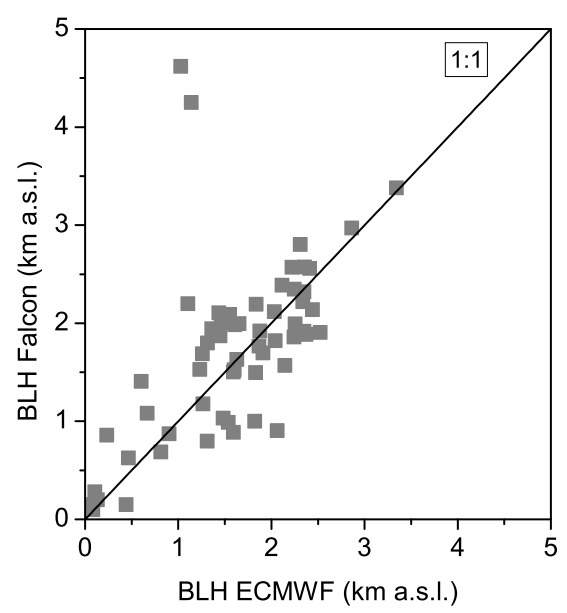

Fig. A2. Comparison of boundary layer height blh (km a.s.1.) from in-situ measurements of DLR Falcon 20 with ECMWF model analysis data.

a horizontal resolution of $\sim 47 \mathrm{~km}$ does not cover all surface specifications which might lead to an deviation of the boundary layer height of a few tens to a hundreds of metres.

The correlation coefficient for the comparison of model boundary layer height and boundary layer height retrieved from DLR Falcon 20 measurements was 0.62 . The correlation is still statistically significant at the $99 \%$ confidence level.
The high correlations of the meteorological parameters give credibility to the use of the model data and the interpolation method used for the trajectory analysis. The boundary layer height retrieved from the ECMWF can be considered as suitable for the analysis of ground based source contributions to the air masses, which are advected along the calculated trajectories.

Acknowledgements. This work has been partly funded by EUCAARI (European Integrated project on Aerosol Cloud Climate and Air Quality interactions) No 036833-2. The authors thank the staff member of the ground based measurement sites and the teams working aboard the FAAM BAe-146 and DLR Falcon 20 during the EUCAARI-LONGREX campaign. The authors especially want to thank Andreas Dörnbrack for his work and help on the meteorological forecast during the campaign and the subsequent analysis. More information about EUCAARI-LONGREX can be found on http:// www.pa.op.dlr.de/aerosol/eucaari2008/. The authors also thank the members of the EDGAR team for providing the EDGARv4.1 emission database - source: European Commission, Joint Research Centre (JRC)/Netherlands Environmental Assessment Agency (PBL). Emission Database for Global Atmospheric Research (EDGAR), release version 4.1. http://edgar.jrc.ec.europa.eu, 2010. Final preparation for the publication was funded by the Bert Bolin Centre for Climate Research (BBCC), Stockholm University. The service charges for this open access publication have been covered by the Amazonian vegetation impacts on aerosols and clouds (AVIAC) project, Swedish Research Council (Vetenskaprådet).

In memory of Hans Rüba, a dear colleague and good friend.

Edited by: V.-M. Kerminen

\section{References}

Ansmann, A., Wandinger, U., Wiedensohler, A., and Leiterer, U.: Lindenberg Aerosol Characterization Experiment 1998 (LACE 98): Overview, J. Geophys. Res., 107, 8129, doi:10.1029/2000JD000233, 2002.

Asmi, A., Wiedensohler, A., Laj, P., Fjaeraa, A.-M., Sellegri, K., Birmili, W., Weingartner, E., Baltensperger, U., Zdimal, V., Zikova, N., Putaud, J.-P., Marinoni, A., Tunved, P., Hansson, H.C., Fiebig, M., Kivekäs, N., Lihavainen, H., Asmi, E., Ulevicius, V., Aalto, P. P., Swietlicki, E., Kristensson, A., Mihalopoulos, N., Kalivitis, N., Kalapov, I., Kiss, G., de Leeuw, G., Henzing, B., Harrison, R. M., Beddows, D., O’Dowd, C., Jennings, S. G., Flentje, H., Weinhold, K., Meinhardt, F., Ries, L., and Kulmala, M.: Number size distributions and seasonality of submicron particles in Europe 2008-2009, Atmos. Chem. Phys., 11, 55055538, doi:10.5194/acp-11-5505-2011, 2011.

Birmili, W., Wiedensohler, A., Heintzenberg, J., and Lehmann, K.: Atmospheric particle number size distribution in central Europe: Statistical relations to air masses and meteorology, J. Geophys. Res., 106, 32005-32018, doi:10.1029/2000JD000220, 2001.

Bohren, C. F. and Huffman, D. R.: Absorption and scattering of light by small particles, John Wiley \& Sons, Inc., New York, 1983. 
Bond, T. C., Streets, D. G., Yarber, K. F., Nelson, S. M., Woo, J.-H., and Klimont, Z.: A technology-based global inventory of black and organic carbon emissions from combustion, J. Geophys. Res., 109, D14203, doi:10.1029/2003JD003697, 2004.

Booth, B. B. B., Dunstone, N. J., Halloran, P. R., Andrews, T., and Bellouin, N.: Aerosols implicated as a prime driver of twentiethcentury North Atlantic climate variability, Nature, 484, 228-232, doi:10.1038/nature10946, 2012.

Boulon, J., Sellegri, K., Hervo, M., Picard, D., Pichon, J.-M., Fréville, P., and Laj, P.: Investigation of nucleation events vertical extent: a long term study at two different altitude sites, Atmos. Chem. Phys., 11, 5625-5639, doi:10.5194/acp-11-56252011, 2011.

Brenninkmeijer, C. A. M., Crutzen, P. J., Fischer, H., Güsten, H., Hans, W., Heinrich, G., Heintzenberg, J., Hermann, M., Immelmann, T., Kersting, D., Maiss, M., Nolle, M., Pitscheider, A., Pohlkamp, H., Scharffe, D., Specht, K., and Wiedensohler, A.: CARIBIC - Civil Aircraft for Global Measurement of Trace Gases and Aerosols in the Tropopause Region, J. Atmos. Ocean. Technol., 16, 1373-1383, doi:10.1175/15200426(1999)016<1373:CCAFGM > 2.0.CO;2, 1999.

Brenninkmeijer, C. A. M., Crutzen, P., Boumard, F., Dauer, T., Dix, B., Ebinghaus, R., Filippi, D., Fischer, H., Franke, H., Frieß, U., Heintzenberg, J., Helleis, F., Hermann, M., Kock, H. H., Koeppel, C., Lelieveld, J., Leuenberger, M., Martinsson, B. G., Miemczyk, S., Moret, H. P., Nguyen, H. N., Nyfeler, P., Oram, D., O’Sullivan, D., Penkett, S., Platt, U., Pupek, M., Ramonet, M., Randa, B., Reichelt, M., Rhee, T. S., Rohwer, J., Rosenfeld, K., Scharffe, D., Schlager, H., Schumann, U., Slemr, F., Sprung, D., Stock, P., Thaler, R., Valentino, F., van Velthoven, P., Waibel, A., Wandel, A., Waschitschek, K., Wiedensohler, A., Xueref-Remy, I., Zahn, A., Zech, U., and Ziereis, H.: Civil Aircraft for the regular investigation of the atmosphere based on an instrumented container: The new CARIBIC system, Atmos. Chem. Phys., 7, 4953-4976, doi:10.5194/acp-7-4953-2007, 2007.

Brock, C. A., Jonsson, H. H., Wilson, J. C., Dye, J. E., Baumgardner, D., Borrmann, S., Pitts, M. C., Osborn, M. T., DeCoursey, R. J., and Woods, D. C.: Relationships between optical extinction, backscatter and aerosol surface and volume in the stratosphere following the eruption of Mt. Pinatubo, Geophys. Res. Lett., 20, 2555-2558, doi:10.1029/93GL01691, 1993.

Clarke, A. and Kapustin, V.: Hemispheric Aerosol Vertical Profiles: Anthropogenic Impacts on Optical Depth and Cloud Nuclei, Science, 329, 1488-1492, doi:10.1126/science.1188838, 2010.

Crumeyrolle, S., Manninen, H. E., Sellegri, K., Roberts, G., Gomes, L., Kulmala, M., Weigel, R., Laj, P., and Schwarzenboeck, A.: New particle formation events measured on board the ATR-42 aircraft during the EUCAARI campaign, Atmos. Chem. Phys., 10, 6721-6735, doi:10.5194/acp-10-6721-2010, 2010.

Dall'Osto, M., Ceburnis, D., Martucci, G., Bialek, J., Dupuy, R., Jennings, S. G., Berresheim, H., Wenger, J., Healy, R., Facchini, M. C., Rinaldi, M., Giulianelli, L., Finessi, E., Worsnop, D., Ehn, M., Mikkilä, J., Kulmala, M., and O'Dowd, C. D.: Aerosol properties associated with air masses arriving into the North East Atlantic during the 2008 Mace Head EUCAARI intensive observing period: an overview, Atmos. Chem. Phys., 10, 8413-8435, doi:10.5194/acp-10-8413-2010, 2010.

Engler, C., Rose, D., Wehner, B., Wiedensohler, A., Brüggemann, E., Gnauk, T., Spindler, G., Tuch, T., and Birmili, W.: Size distri- butions of non-volatile particle residuals $\left(D_{\mathrm{p}}<800 \mathrm{~nm}\right)$ at a rural site in Germany and relation to air mass origin, Atmos. Chem. Phys., 7, 5785-5802, doi:10.5194/acp-7-5785-2007, 2007.

Esselborn, M., Wirth, M., Fix, A., Tesche, M., and Ehret, G.: Airborne high spectral resolution lidar for measuring aerosol extinction and backscatter coefficients, Appl. Opt., 47, 346-358, doi:10.1364/AO.47.000346, 2008.

Feldpausch, P., Fiebig, M., Fritzsche, L., and Petzold, A.: Measurement of ultrafine aerosol size distributions by a combination of diffusion screen separators and condensation particle counters, J. Aerosol Sci., 37, 577-597, doi:10.1016/j.jaerosci.2005.04.009, 2006.

Fiebig, M.: Das troposphärische Aerosol in mittleren Breiten Mikrophysik, Optik und Klimaantrieb am Beispiel der Feldstudie LACE 98, Ph.D. thesis, Ludwig-Maximilians-Universität, München, Germany, 2001.

Fiebig, M., Stein, C., Schröder, F., Feldpausch, P., and Petzold, A.: Inversion of data containing information on the aerosol particle size distribution using multiple instruments, J. Aerosol Sci., 36, 1353-1372, doi:10.1016/j.jaerosci.2005.01.004, 2005.

Forster, P., Ramaswamy, V., Artaxo, P., Berntsen, T., Betts, R., Fahey, D., Haywood, J., Lean, J., Lowe, D., Myhre, G., Nganga, J., Prinn, R., Raga, G., Schulz, M., and Dorland, R. V.: Changes in Atmospheric Constituents and in Radiative Forcing. In: Climate Change 2007: The Physical Science Basis. Contribution of Working Group I to the Fourth Assessment Report of the Intergovernmental Panel on Climate Change, Cambridge University Press, Cambridge, United Kingdom and New York, NY, USA, http://www.ipcc.ch/publications_and_data/ar4/ wg1/en/ch2.html, 2007.

Hamburger, T.: Aerosol microphysical properties during anticyclonic flow conditions over Europe, Ph.D. thesis, LudwigMaximilians-Universität, München, http://nbn-resolving.de/urn: nbn:de:bvb:19-127766, 2011.

Hamburger, T., McMeeking, G., Minikin, A., Birmili, W., Dall'Osto, M., O’Dowd, C., Flentje, H., Henzing, B., Junninen, H., Kristensson, A., de Leeuw, G., Stohl, A., Burkhart, J. F., Coe, H., Krejci, R., and Petzold, A.: Overview of the synoptic and pollution situation over Europe during the EUCAARILONGREX field campaign, Atmos. Chem. Phys., 11, 10651082, doi:10.5194/acp-11-1065-2011, 2011.

Haywood, J. and Boucher, O.: Estimates of the direct and indirect radiative forcing due to tropospheric aerosols: A review, Rev. Geophys., 38, 513-543, doi:10.1029/1999RG000078, 2000.

Highwood, E. J., Northway, M. J., McMeeking, G. R., Morgan, W. T., Liu, D., Osborne, S., Bower, K., Coe, H., Ryder, C., and Williams, P.: Aerosol scattering and absorption during the EUCAARI-LONGREX flights of the Facility for Airborne Atmospheric Measurements (FAAM) BAe-146: can measurements and models agree?, Atmos. Chem. Phys., 12, 7251-7267, doi:10.5194/acp-12-7251-2012, 2012.

Iorga, G., Hitzenberger, R., Kasper-Giebl, A., and Puxbaum, H.: Direct radiative effect modeled for regional aerosols in central Europe including the effect of relative humidity, J. Geophys. Res., 112, D01204, doi:10.1029/2005JD006828, 2007.

Jimenez, J. L., Canagaratna, M. R., Donahue, N. M., Prevot, A. S. H., Zhang, Q., Kroll, J. H., DeCarlo, P. F., Allan, J. D., Coe, H., Ng, N. L., Aiken, A. C., Docherty, K. S., Ulbrich, I. M., Grieshop, A. P., Robinson, A. L., Duplissy, J., Smith, J. D. 
Wilson, K. R., Lanz, V. A., Hueglin, C., Sun, Y. L., Tian, J., Laaksonen, A., Raatikainen, T., Rautiainen, J., Vaattovaara, P., Ehn, M., Kulmala, M., Tomlinson, J. M., Collins, D. R., Cubison, M. J., E., Dunlea, J., Huffman, J. A., Onasch, T. B., Alfarra, M. R., Williams, P. I., Bower, K., Kondo, Y., Schneider, J., Drewnick, F., Borrmann, S., Weimer, S., Demerjian, K., Salcedo, D., Cottrell, L., Griffin, R., Takami, A., Miyoshi, T., Hatakeyama, S., Shimono, A., Sun, J. Y., Zhang, Y. M., Dzepina, K., Kimmel, J. R., Sueper, D., Jayne, J. T., Herndon, S. C., Trimborn, A. M., Williams, L. R., Wood, E. C., Middlebrook, A. M., Kolb, C. E., Baltensperger, U., and Worsnop, D. R.: Evolution of Organic Aerosols in the Atmosphere, Science, 326, 1525-1529, doi:10.1126/science.1180353, 2009.

Johnson, G., Ristovski, Z., and Morawska, L.: Method for measuring the hygroscopic behaviour of lower volatility fractions in an internally mixed aerosol, J. Aerosol Sci., 35, 443-455, doi:10.1016/j.jaerosci.2003.10.008, 2004.

Kulmala, M. and Kerminen, V.-M.: On the formation and growth of atmospheric nanoparticles, Atmospheric Research, 90, 132-150, doi:10.1016/j.atmosres.2008.01.005, 17th International Conference on Nucleation and Atmospheric Aerosols ICNAA07, 2008.

Kulmala, M., Asmi, A., Lappalainen, H. K., Carslaw, K. S., Pöschl, U., Baltensperger, U., Hov, ., Brenquier, J.-L., Pandis, S. N., Facchini, M. C., Hansson, H.-C., Wiedensohler, A., and O'Dowd, C. D.: Introduction: European Integrated Project on Aerosol Cloud Climate and Air Quality interactions (EUCAARI) - integrating aerosol research from nano to global scales, Atmos. Chem. Phys., 9, 2825-2841, doi:10.5194/acp-9-2825-2009, 2009.

Kulmala, M., Asmi, A., Lappalainen, H. K., Baltensperger, U., Brenguier, J.-L., Facchini, M. C., Hansson, H.-C., Hov, Ø., O'Dowd, C. D., Pöschl, U., Wiedensohler, A., Boers, R., Boucher, O., de Leeuw, G., Denier van der Gon, H. A. C., Feichter, J., Krejci, R., Laj, P., Lihavainen, H., Lohmann, U., McFiggans, G., Mentel, T., Pilinis, C., Riipinen, I., Schulz, M., Stohl, A., Swietlicki, E., Vignati, E., Alves, C., Amann, M., Ammann, M., Arabas, S., Artaxo, P., Baars, H., Beddows, D. C. S., Bergström, R., Beukes, J. P., Bilde, M., Burkhart, J. F., Canonaco, F., Clegg, S. L., Coe, H., Crumeyrolle, S., D’Anna, B., Decesari, S., Gilardoni, S., Fischer, M., Fjaeraa, A. M., Fountoukis, C., George, C., Gomes, L., Halloran, P., Hamburger, T., Harrison, R. M., Herrmann, H., Hoffmann, T., Hoose, C., Hu, M., Hyvärinen, A., Hõrrak, U., Iinuma, Y., Iversen, T., Josipovic, M., Kanakidou, M., Kiendler-Scharr, A., Kirkevåg, A., Kiss, G., Klimont, Z., Kolmonen, P., Komppula, M., Kristjánsson, J.-E., Laakso, L., Laaksonen, A., Labonnote, L., Lanz, V. A., Lehtinen, K. E. J., Rizzo, L. V., Makkonen, R., Manninen, H. E., McMeeking, G., Merikanto, J., Minikin, A., Mirme, S., Morgan, W. T., Nemitz, E., O’Donnell, D., Panwar, T. S., Pawlowska, H., Petzold, A., Pienaar, J. J., Pio, C., Plass-Duelmer, C., Prévôt, A. S. H., Pryor, S., Reddington, C. L., Roberts, G., Rosenfeld, D., Schwarz, J., Seland, Ø., Sellegri, K., Shen, X. J., Shiraiwa, M., Siebert, H., Sierau, B., Simpson, D., Sun, J. Y., Topping, D., Tunved, P., Vaattovaara, P., Vakkari, V., Veefkind, J. P., Visschedijk, A., Vuollekoski, H., Vuolo, R., Wehner, B., Wildt, J., Woodward, S., Worsnop, D. R., van Zadelhoff, G.-J., Zardini, A. A., Zhang, K., van Zyl, P. G., Kerminen, V.-M., S Carslaw, K., and Pandis, S. N.: General overview: European Integrated project on Aerosol Cloud Climate and Air Quality interactions
(EUCAARI) - integrating aerosol research from nano to global scales, Atmos. Chem. Phys., 11, 13061-13143, doi:10.5194/acp11-13061-2011, 2011.

Laj, P., Klausen, J., Bilde, M., Plaß-Duelmer, C., Pappalardo, G., Clerbaux, C., Baltensperger, U., Hjorth, J., Simpson, D., Reimann, S., Coheur, P.-F., Richter, A., Mazière, M. D., Rudich, Y., McFiggans, G., Torseth, K., Wiedensohler, A., Morin, S., Schulz, M., Allan, J., Attié, J.-L., Barnes, I., Birmili, W., Cammas, J., Dommen, J., Dorn, H.-P., Fowler, D., Fuzzi, S., Glasius, M., Granier, C., Hermann, M., Isaksen, I., Kinne, S., Koren, I., Madonna, F., Maione, M., Massling, A., Moehler, O., Mona, L., Monks, P., Müller, D., Müller, T., Orphal, J., Peuch, V.-H., Stratmann, F., Tanré, D., Tyndall, G., Riziq, A. A., Roozendael, M. V., Villani, P., Wehner, B., Wex, H., and Zardini, A.: Measuring atmospheric composition change, Atmos. Environ., 43, 53515414, doi:10.1016/j.atmosenv.2009.08.020, aCCENT Synthesis, 2009.

Liu, P. S. K., Leaitch, W. R., Strapp, J. W., and Wasey, M. A.: Response of Particle Measuring Systems Airborne ASASP and PCASP to $\mathrm{NaCl}$ and Latex Particles, Aerosol Sci. Technol., 16, 83-95, doi:10.1080/02786829208959539, 1992.

Lohmann, U. and Feichter, J.: Global indirect aerosol effects: a review, Atmos. Chem. Phys., 5, 715-737, doi:10.5194/acp-5-7152005, 2005.

McMeeking, G. R., Hamburger, T., Liu, D., Flynn, M., Morgan, W. T., Northway, M., Highwood, E. J., Krejci, R., Allan, J. D., Minikin, A., and Coe, H.: Black carbon measurements in the boundary layer over western and northern Europe, Atmos. Chem. Phys., 10, 9393-9414, doi:10.5194/acp-10-9393-2010, 2010.

McMeeking, G. R., Morgan, W. T., Flynn, M., Highwood, E. J., Turnbull, K., Haywood, J., and Coe, H.: Black carbon aerosol mixing state, organic aerosols and aerosol optical properties over the United Kingdom, Atmospheric Chemistry and Physics, 11, 9037-9052, doi:10.5194/acp-11-9037-2011, 2011.

Minikin, A., Petzold, A., Ström, J., Krejci, R., Seifert, M., van Velthoven, P., Schlager, H., and Schumann, U.: Aircraft observations of the upper tropospheric fine particle aerosol in the Northern and Southern Hemispheres at midlatitudes, Geophys. Res. Lett., 30, 1503, doi:10.1029/2002GL016458, 2003.

Mirme, S., Mirme, A., Minikin, A., Petzold, A., Hõrrak, U., Kerminen, V. M., and Kulmala, M.: Atmospheric sub-3 nm particles at high altitudes, Atmos. Chem. Phys., 10, 437-451, doi:10.5194/acp-10-437-2010, 2010.

Morgan, W. T., Allan, J. D., Bower, K. N., Esselborn, M., Harris, B., Henzing, J. S., Highwood, E. J., Kiendler-Scharr, A., McMeeking, G. R., Mensah, A. A., Northway, M. J., Osborne, S., Williams, P. I., Krejci, R., and Coe, H.: Enhancement of the aerosol direct radiative effect by semi-volatile aerosol components: airborne measurements in North-Western Europe, Atmos. Chem. Phys., 10, 8151-8171, doi:10.5194/acp-10-81512010, 2010a.

Morgan, W. T., Allan, J. D., Bower, K. N., Highwood, E. J., Liu, D., McMeeking, G. R., Northway, M. J., Williams, P. I., Krejci, R., and Coe, H.: Airborne measurements of the spatial distribution of aerosol chemical composition across Europe and evolution of the organic fraction, Atmos. Chem. Phys., 10, 4065-4083, doi:10.5194/acp-10-4065-2010, 2010b.

O'Connor, T., Jennings, S., and O'Dowd, C.: Highlights of fifty years of atmospheric aerosol research at Mace Head, Atmos. 
Res., 90, 338-355, doi:10.1016/j.atmosres.2008.08.014, 17th International Conference on Nucleation and Atmospheric Aerosols - ICNAA07, 2008.

Petzold, A., Döpelheuer, A., Brock, C. A., and Schröder, F.: In situ observations and model calculations of black carbon emission by aircraft at cruise altitude, J. Geophys. Res., 104, 22171-22181, doi:10.1029/1999JD900460, 1999.

Petzold, A., Fiebig, M., Flentje, H., Keil, A., Leiterer, U., Schröder, F., Stifter, A., Wendisch, M., and Wendling, P.: Vertical variability of aerosol properties observed at a continental site during the Lindenberg Aerosol Characterization Experiment (LACE 98), J. Geophys. Res., 107, 8128, doi:10.1029/2001JD001043, 2002.

Péré, J. C., Mallet, M., Pont, V., and Bessagnet, B.: Impact of aerosol direct radiative forcing on the radiative budget, surface heat fluxes, and atmospheric dynamics during the heat wave of summer 2003 over western Europe: A modeling study, J. Geophys. Res., 116, D23119, doi:10.1029/2011JD016240, 2011.

Putaud, J.-P., Raes, F., Dingenen, R. V., Brüggemann, E., Facchini, M. C., Decesari, S., Fuzzi, S., Gehrig, R., Hüglin, C., Laj, P., Lorbeer, G., Maenhaut, W., Mihalopoulos, N., Müller, K., Querol, X., Rodriguez, S., Schneider, J., Spindler, G., ten Brink, H., Tørseth, K., and Wiedensohler, A.: A European aerosol phenomenology-2: chemical characteristics of particulate matter at kerbside, urban, rural and background sites in Europe, Atmos. Environ., 38, 2579-2595, doi:10.1016/j.atmosenv.2004.01.041, 2004.

Putaud, J.-P., Dingenen, R. V., Alastuey, A., Bauer, H., Birmili, W., Cyrys, J., Flentje, H., Fuzzi, S., Gehrig, R., Hansson, H., Harrison, R., Herrmann, H., Hitzenberger, R., Hüglin, C., Jones, A., Kasper-Giebl, A., Kiss, G., Kousa, A., Kuhlbusch, T., Löschau, G., Maenhaut, W., Molnar, A., Moreno, T., Pekkanen, J., Perrino, C., Pitz, M., Puxbaum, H., Querol, X., Rodriguez, S., Salma, I., Schwarz, J., Smolik, J., Schneider, J., Spindler, G., ten Brink, H., Tursic, J., Viana, M., Wiedensohler, A., and Raes, F.: A European aerosol phenomenology - 3: Physical and chemical characteristics of particulate matter from 60 rural, urban, and kerbside sites across Europe, Atmos. Environ., 44, 1308-1320, doi:10.1016/j.atmosenv.2009.12.011, 2010.

Reddington, C. L., Carslaw, K. S., Spracklen, D. V., Frontoso, M. G., Collins, L., Merikanto, J., Minikin, A., Hamburger, T., Coe, H., Kulmala, M., Aalto, P., Flentje, H., Plass-Dülmer, C., Birmili, W., Wiedensohler, A., Wehner, B., Tuch, T., Sonntag, A., O’Dowd, C. D., Jennings, S. G., Dupuy, R., Baltensperger, U., Weingartner, E., Hansson, H.-C., Tunved, P., Laj, P., Sellegri, K., Boulon, J., Putaud, J.-P., Gruening, C., Swietlicki, E., Roldin, P., Henzing, J. S., Moerman, M., Mihalopoulos, N., Kouvarakis, G., Ždímal, V., Zíková, N., Marinoni, A., Bonasoni, P., and Duchi, R.: Primary versus secondary contributions to particle number concentrations in the European boundary layer, Atmos. Chem. Phys., 11, 12007-12036, doi:10.5194/acp-11-12007-2011, 2011.

Riemer, N., Vogel, H., and Vogel, B.: Soot aging time scales in polluted regions during day and night, Atmos. Chem. Phys., 4, 1885-1893, doi:10.5194/acp-4-1885-2004, 2004.

Roldin, P., Swietlicki, E., Massling, A., Kristensson, A., Löndahl, J., Eriksson, A., Pagels, J., and Gustafsson, S.: Aerosol ageing in an urban plume - implication for climate, Atmos. Chem. Phys., 11, 5897-5915, doi:10.5194/acp-11-5897-2011, 2011.

Schröder, F., Kärcher, B., Fiebig, M., and Petzold, A.: Aerosol states in the free troposphere at northern midlatitudes, J. Geophys. Res.,
107, 8126, doi:10.1029/2000JD000194, 2002.

Schröder, F. P., Kärcher, B., Petzold, A., Baumann, R., Busen, R., Hoell, C., and Schumann, U.: Ultrafine aerosol particles in aircraft plumes: In situ observations, Geophys. Res. Lett., 25, 27892792, doi:10.1029/98GL02078, 1998.

Shindell, D. and Faluvegi, G.: Climate response to regional radiative forcing during the twentieth century, Nature Geosci., 2, 294-300, doi:10.1038/ngeo473, 2009.

Singh, H. B., Anderson, B. E., Avery, M. A., Viezee, W., Chen, Y., Tabazadeh, A., Hamill, P., Pueschel, R., Fuelberg, H. E., and Hannan, J. R.: Global distribution and sources of volatile and nonvolatile aerosol in the remote troposphere, J. Geophys. Res., 107, 4121, doi:10.1029/2001JD000486, 2002.

Slanina, J., Lamoen-doornenbal, L. V., Lingerak, W. A., Meilof, W., Klockow, D., and Nießner, R.: Application of a ThermoDenuder Analyser to the Determination of H2SO4, HNO3 and NH3 in Air, Int. J. Environ. Analyt. Chem., 9, 59-70, doi:10.1080/03067318108071509, 1981.

Stock, M., Cheng, Y. F., Birmili, W., Massling, A., Wehner, B., Müller, T., Leinert, S., Kalivitis, N., Mihalopoulos, N., and Wiedensohler, A.: Hygroscopic properties of atmospheric aerosol particles over the Eastern Mediterranean: implications for regional direct radiative forcing under clean and polluted conditions, Atmos. Chem. Phys., 11, 4251-4271, doi:10.5194/acp11-4251-2011, 2011.

Stohl, A., Forster, C., Frank, A., Seibert, P., and Wotawa, G.: Technical note: The Lagrangian particle dispersion model FLEXPART version 6.2, Atmos. Chem. Phys., 5, 2461-2474, doi:10.5194/acp-5-2461-2005, 2005.

Troen, I. B. and Mahrt, L.: A simple model of the atmospheric boundary layer; sensitivity to surface evaporation, Bound.-Layer Meteorol., 37, 129-148, doi:10.1007/BF00122760, 1986.

Van Dingenen, R., Raes, F., Putaud, J.-P., Baltensperger, U., Charron, A., Facchini, M. C., Decesari, S., Fuzzi, S., Gehrig, R., Hansson, H.-C., Harrison, R. M., Hüglin, C., Jones, A. M., Laj, P., Lorbeer, G., Maenhaut, W., Palmgren, F., Querol, X., Rodriguez, S., Schneider, J., ten Brink, H., Tunved, P., Tørseth, K., Wehner, B., Weingartner, E., Wiedensohler, A., and Wåhlin, P.: A European aerosol phenomenology-1: physical characteristics of particulate matter at kerbside, urban, rural and background sites in Europe, Atmos. Environ., 38, 2561-2577, doi:10.1016/j.atmosenv.2004.01.040, 2004.

Venzac, H., Sellegri, K., Villani, P., Picard, D., and Laj, P.: Seasonal variation of aerosol size distributions in the free troposphere and residual layer at the puy de Dôme station, France, Atmos. Chem. Phys., 9, 1465-1478, doi:10.5194/acp-9-1465-2009, 2009.

Voigt, C., Schumann, U., Jurkat, T., Schäuble, D., Schlager, H., Petzold, A., Gayet, J.-F., Krämer, M., Schneider, J., Borrmann, S., Schmale, J., Jessberger, P., Hamburger, T., Lichtenstern, M., Scheibe, M., Gourbeyre, C., Meyer, J., Kübbeler, M., Frey, W., Kalesse, H., Butler, T., Lawrence, M. G., Holzäpfel, F., Arnold, F., Wendisch, M., Döpelheuer, A., Gottschaldt, K., Baumann, R., Zöger, M., Sölch, I., Rautenhaus, M., and Dörnbrack, A.: In-situ observations of young contrails - overview and selected results from the CONCERT campaign, Atmos. Chem. Phys., 10, 90399056, doi:10.5194/acp-10-9039-2010, 2010.

Weinzierl, B., Sauer, D., Esselborn, M., Petzold, A., Veira, A., Rose, M., Mund, S., Wirth, M., Ansmann, A., Tesche, M., Groß, S., and Freudenthaler, V.: Microphysical and optical properties of dust 
and tropical biomass burning aerosol layers in the Cape Verde region - an overview of the airborne in situ and lidar measurements during SAMUM-2, Tellus B, 63, 589-618, doi:10.1111/j.16000889.2011.00566.x, 2011.

Wernli, B. H. and Davies, H. C.: A lagrangian-based analysis of extratropical cyclones. I: The method and some applications, Q. J. Roy. Meteorol. Soc., 123, 467-489, doi:10.1002/qj.49712353811, 1997.
Wernli, H.: A lagrangian-based analysis of extratropical cyclones. II: A detailed case-study, Q. J. Roy. Meteorol. Soc., 123, 16771706, doi:10.1002/qj.49712354211, 1997.

Williams, J., de Reus, M., Krejci, R., Fischer, H., and Ström, J.: Application of the variability-size relationship to atmospheric aerosol studies: estimating aerosol lifetimes and ages, Atmos. Chem. Phys., 2, 133-145, doi:10.5194/acp-2-133-2002, 2002. 